Biogeosciences, 10, 4991-5007, 2013

www.biogeosciences.net/10/4991/2013/

doi:10.5194/bg-10-4991-2013

(C) Author(s) 2013. CC Attribution 3.0 License.

\title{
Si cycling in a forest biogeosystem - the importance of transient state biogenic Si pools
}

\author{
M. Sommer ${ }^{1,2}$, H. Jochheim ${ }^{3}$, A. Höhn ${ }^{1}$, J. Breuer ${ }^{4}$, Z. Zagorski ${ }^{5}$, J. Busse ${ }^{6}$, D. Barkusky ${ }^{7}$, K. Meier ${ }^{8}$, D. Puppe ${ }^{1,9}$, \\ M. Wanner ${ }^{9}$, and D. Kaczorek ${ }^{1,5}$ \\ ${ }^{1}$ Leibniz Centre for Agricultural Landscape Research (ZALF), Institute of Soil Landscape Research, Eberswalder Str. 84, \\ 15374 Müncheberg, Germany \\ ${ }^{2}$ University of Potsdam, Institute of Earth and Environmental Sciences, Karl-Liebknecht-Str. 24-25, 14476 Potsdam, \\ Germany \\ ${ }^{3}$ Leibniz Centre for Agricultural Landscape Research (ZALF), Institute of Landscape Systems Analysis, Eberswalder Str. 84, \\ 15374 Müncheberg, Germany \\ ${ }^{4}$ Landwirtschaftliches Technologiezentrum Augustenberg (LTZ), Referat 12, Neßlerstr. 23-32, 76227 Karlsruhe, Germany \\ ${ }^{5}$ Department of Soil Environment Sciences, Warsaw University of Life Science (SGGW), Nowoursynowska 159, 02-776 \\ Warsaw, Poland \\ ${ }^{6}$ Leibniz Centre for Agricultural Landscape Research (ZALF), Institute for Landscape Biogeochemistry, Eberswalder Str. 84, \\ 15374 Müncheberg, Germany \\ ${ }^{7}$ Leibniz Centre for Agricultural Landscape Research (ZALF), Research Station Müncheberg, Eberswalder Str. 84, 15374 \\ Müncheberg, Germany \\ ${ }^{8}$ Leibniz Centre for Agricultural Landscape Research (ZALF), Institute of Land Use Systems, Eberswalder Str. 84, 15374 \\ Müncheberg, Germany \\ ${ }^{9}$ Brandenburg University of Technology Cottbus-Senftenberg, Chair General Ecology, 03013 Cottbus, Germany \\ Correspondence to: M. Sommer (sommer@zalf.de)
}

Received: 30 September 2012 - Published in Biogeosciences Discuss.: 19 December 2012

Revised: 11 June 2013 - Accepted: 18 June 2013 - Published: 24 July 2013

\begin{abstract}
The relevance of biological Si cycling for dissolved silica (DSi) export from terrestrial biogeosystems is still in debate. Even in systems showing a high content of weatherable minerals, like Cambisols on volcanic tuff, biogenic $\mathrm{Si}$ (BSi) might contribute $>50 \%$ to DSi (Gerard et al., 2008). However, the number of biogeosystem studies is rather limited for generalized conclusions. To cover one end of controlling factors on DSi, i.e., weatherable minerals content, we studied a forested site with absolute quartz dominance $(>95 \%)$. Here we hypothesise minimal effects of chemical weathering of silicates on DSi. During a four year observation period (05/2007-04/2011), we quantified (i) internal and external Si fluxes of a temperate-humid biogeosystem (beech, $120 \mathrm{yr}$ ) by BIOME-BGC (version ZALF), (ii) related Si budgets, and (iii) Si pools in soil and beech, chemically as well as by SEM-EDX. For the first time two compartments of biogenic Si in soils were analysed, i.e., phyto-
\end{abstract}

genic and zoogenic Si pool (testate amoebae). We quantified an average Si plant uptake of $35 \mathrm{~kg} \mathrm{Si} \mathrm{ha}^{-1} \mathrm{yr}^{-1}-$ most of which is recycled to the soil by litterfall - and calculated an annual biosilicification from idiosomic testate amoebae of $17 \mathrm{~kg} \mathrm{Si} \mathrm{ha}^{-1}$. The comparatively high DSi concentrations $\left(6 \mathrm{mg} \mathrm{L}^{-1}\right)$ and DSi exports $\left(12 \mathrm{~kg} \mathrm{Si} \mathrm{ha}^{-1} \mathrm{yr}^{-1}\right)$ could not be explained by chemical weathering of feldspars or quartz dissolution. Instead, dissolution of a relictic, phytogenic $\mathrm{Si}$ pool seems to be the main process for the DSi observed. We identified canopy closure accompanied by a disappearance of grasses as well as the selective extraction of pine trees $30 \mathrm{yr}$ ago as the most probable control for the phenomena observed. From our results we concluded the biogeosystem to be in a transient state in terms of Si cycling. 


\section{Introduction}

In recent years our understanding of $\mathrm{Si}$ cycling in different terrestrial biogeosystems has been improved substantially. Research on steppe (Blecker et al., 2006; Borrelli et al., 2010, White et al., 2012), savannah (Melzer et al., 2010, 2012; Alexandre et al., 2011), forest (Gerard et al., 2008; Cornelis et al., 2010a, 2011a) and wetland biogeosystems (Struyf and Conley, 2009; Struyf et al., 2009) enhanced our understanding of the "plant factor", i.e., the importance of the biological $\mathrm{Si}$ cycling in terrestrial biogeosystems which had been studied in tropical and temperate climates so far (Sommer et al., 2006).

Recently, the complex effects of natural disturbances and anthropogenic perturbations on Si cycling came into focus in Si research. Deforestation (Conley et al., 2008), invading insects (Grady et al., 2007), or fire (Engle et al., 2008) clearly modifies annual DSi exports from catchments. Land use change (LUC) was added as another control on DSi exports at regional scale and conceptual models including those for human activities were developed (Struyf et al. 2010; Carey and Fulweiler, 2012). The results of these studies challenge the steady state assumption implied in most studies on Si budgets.

Although a spatial hierarchy of driving factors for DSi exports is well known (Sommer et al., 2006; Cornelis et al., $2011 b$ ), the origin of DSi is still under debate. The major research questions are the following: How large is the contribution of BSi pool to DSi compared to litho-/pedogenic sources? What are the main drivers of the relative importance of biogenic and mineral sources - climate, lithology, state of soil development, soil pattern, land use? To answer these questions Cornelis et al. (2011b) developed a conceptual framework. They defined four different scenarios ("end members") based on climate, soil, and vegetation: scenario 1 (weathering unlimited) represents optimal climate and soil conditions. Here the DSi exports from soil-plant systems are controlled by climate, i.e., temperature and runoff. In scenario 2 (soil weathering limited) climate is optimal, but soils are poor in weatherable minerals. Consequently, DSi export is controlled by a near-surface biogeochemical cycling in the plant-soil system rather than by geochemical processes in deeper soil layer. In scenario 3 (climate weathering limited) soils contain weatherable minerals. Therefore, DSi might be controlled by either biogenic or pedo-/lithogenic sources. Their relative proportions depend on local conditions (lithology, geomorphology, land use). By scenario 4 (weathering limited) deserts are covered where eolian fluxes are the only relevant $\mathrm{Si}$ export from the system. According to Cornelis et al. (2011b) each scenario should be characterized by distinct DSi geochemical signatures $\left(\delta^{30} \mathrm{Si}, \mathrm{Ge} / \mathrm{Si}\right)$ which can be used in tracing Si pathways in soil-plant systems.

However these signatures have to be combined with $\mathrm{Si}$ flux analysis (incl. mass balances) and Si pool quantifications in order to understand the fate of $\mathrm{Si}$ in terrestrial bio- geosystems. Unfortunately, the number of studies in which Si fluxes in/from the soil-plant system are directly linked to a detailed analysis of Si pools is still limited (e.g., Alexandre et al., 1997; Lucas, 2003; Blecker et al. 2006; Gerard et al., 2008; White et al. 2012). Furthermore, no study included a zoogenic Si pool, although first results on testate amoebae dynamics already showed its relevance in terms of biosilicification (comparable to plants, Aoki et al., 2007).

Here we present results on Si cycling in a forest biogeosystem which experienced vegetation shifts due to forest management. We hypothesised that the effects of Si biocycling on DSi must be most pronounced in cases of very low silicate weathering. Therefore, we selected a biogeosystem showing a quartz dominance in soils and parent material $(>95 \%)$. Based on a system approach, we quantified Si fluxes (internal, external) for a $4 \mathrm{yr}$ period and interpreted DSi exports in terms of litho-/pedogenic and biogenic sources as well as vegetation shifts. For the first time the quantification of the biogenic Si pool comprises two compartments, the phytogenic and zoogenic pool.

\section{Materials and methods}

\subsection{Environmental setting}

Our study site "Beerenbusch" is located in northern Brandenburg close to the village Rheinsberg $\left(53^{\circ} 09^{\prime} \mathrm{N}, 12^{\circ} 59^{\prime} \mathrm{E}\right.$; 78 ma.s.1.; Fig. S1 in Supplement). The climate is characterised by mean annual air temperature of $8.7^{\circ} \mathrm{C}$ and average precipitation of $600 \mathrm{~mm} \mathrm{y}^{-1}$ according to long-term measurements (1981-2010) of the meteorological station Neuglobsow/Menz of the German Weather Service (DWD) which is located $4 \mathrm{kmE}$ of the forest stand. The mean precipitation during the study period (05/2007-04/2011) was $15 \%$ higher $(689 \mathrm{~mm})$ compared to the $30 \mathrm{yr}$ average.

The study site is located at a Weichselian outwash plain (sandur) of the Rheinsberg Basin in the foreland of Late Pleistocene terminal moraines ("Fürstenberger Staffel", Ginzel and Ertl, 2004). The soil is classified as Brunic Arenosol (Dystric) according to WRB (2006) and Lamellic Udipsamment according to Soil Taxonomy (Soil Survey Staff, 1999). Humus enriched topsoils extend down to a depth of $35 \mathrm{~cm}$ (Fig. S2 in Supplement). Bleached quartz grains indicate a slight podzolization for the first mineral horizon (AE). Brunification leads to a bright brownish color in the subsoil (Bw horizons) down to a depth of $80 \mathrm{~cm}$. Single thin clay lamellae in subsoil and parent material indicate clay translocation macroscopically (down to $120 \mathrm{~cm}$ ).

\subsection{Land use and forest management history}

The study site is embedded into a large forested area, called "Naturpark Stechlin-Ruppiner Land". Reconstruction of land use history revealed Beerenbusch to be covered by forests for at least $230 \mathrm{yr}$ (Fig. S3 in Supplement). Before 1888 the site 
was used as pine forest (Pinus sylvestris L., planted in 1826) (Figs. S4, S5 in Supplement). In 1888 European beech (Fagus sylvatica L.) was planted into the pine stand as an understorey. A mixed forest of beech and pine developed since. As canopy closure continued, grasses of the understorey successively disappeared due to light limitation. Already in 1954 only few local spots with grasses in the ground vegetation existed (Table S6 in Supplement). Canopy closure was accomplished in the early 1980s. From 1985 to 1988, the upper pine layer of the mixed forest stand was cut stepwise. The recent plant community classifies as a Majanthemo-Fagetum with coverages of $85 \%$ beech in the upper storey, $5 \%$ in the intermediate layer and $20 \%$ in the understorey. The recent ground vegetation shows herbs ( $1 \%$ coverage), mosses $(5 \%)$, and lichens $(<1 \%)$ (F. Becker, personal communication, 2004), but no grasses (Fig. S3 in Supplement). In 2008 the mature beech stand is characterised by a mean tree height of $28 \mathrm{~m}$ and a timber volume of $369 \mathrm{~m}^{3} \mathrm{ha}^{-1}$. An ICP Forests site (DE1207) was established and instrumented at a 0.5 ha fenced area in 2001 (Fig. S2 in Supplement).

\subsection{Sampling and analysis of soils, plants, phytoliths, and testate amoebae}

A representative soil and a sediment core had been analysed for basic textural and chemical properties prior to this study (Lachmann, 2002; Jochheim et al., 2007a; Fig. S2 in Supplement). Spatial soil heterogeneity was characterized in a $25 \times 25 \mathrm{~m}$ raster by Lachmann (2002). From his results a quite similar soil horizonation and sediment layering can be concluded for the 0.5 ha study site. Therefore, we merged results of both samplings (soil pit, core) into one depth function (down to $2.8 \mathrm{~m}$ ). For $\mathrm{Si}$ analysis a resampling from the original soil pit occurred end of September 2009.

Litter and soil material was taken by horizons down to a depth of $1.25 \mathrm{~m}$ and stored in plastic bags. Undisturbed soil cores $\left(100 \mathrm{~cm}^{3}\right)$ were taken in the middle of soil horizons and dried at $105^{\circ} \mathrm{C}$ for determination of bulk density (BD) (Lachmann, 2002). Bulk densities for sediments of the core were calculated by bulk density $=(1-$ total porosity) $\times$ density. Assuming a total porosity of 0.36 (36 Vol. \%), which is reasonable for near-surface glaciofluvial sands, and a quartz density of $2.65 \mathrm{~g} \mathrm{~cm}^{-3}$ we calculated a bulk density of $1.7 \mathrm{~g} \mathrm{~cm}^{-3}$. Bulk soil samples were air dried, gently crushed and sieved at $2 \mathrm{~mm}$ to separate the fine earth fraction $(<2 \mathrm{~mm})$ from gravel $(>2 \mathrm{~mm})$. The particle size distribution of the fine earth was determined by a combined wet sieving $(>63 \mu \mathrm{m})$ and pipette $(<20 \mu \mathrm{m})$ method (DIN ISO 11277, 1998). Pretreatment for particle size analysis was done by wet oxidation of organic matter using $\mathrm{H}_{2} \mathrm{O}_{2}$ $(10 \mathrm{Vol} . \%)$ at $80^{\circ} \mathrm{C}$ and dispersion by shaking the sample end over end for $16 \mathrm{~h}$ with a $0.01 \mathrm{M} \mathrm{Na}_{4} \mathrm{P}_{2} \mathrm{O}_{7}$-solution (Schlichting et al., 1995). Soil pH was measured using a glass electrode in $0.01 \mathrm{M} \mathrm{CaCl}_{2}$ suspensions at a soil to solution ratio of $1: 5(w / v)$ (DIN ISO 10390, 1997) af- ter a 60 minute equilibration period. The total carbon content was determined by dry combustion using an elemental analyser (Vario EL, Elementar Analysensysteme, Hanau, Germany). $\mathrm{CaCO}_{3}$ was determined conductometrically following Scheibler (Schlichting et al., 1995). Organic carbon $\left(\mathrm{C}_{\mathrm{org}}\right)$ was calculated as the difference between total carbon and carbonate carbon. In soil horizons and sediments without carbonates total carbon equals soil organic carbon. Pedogenic oxides were characterised by dithionite-soluble (DCB) $\mathrm{Fe}\left(\mathrm{Fe}_{\mathrm{d}}\right)$ and dark acid-oxalate soluble $\mathrm{Fe}, \mathrm{Al}$, and $\mathrm{Si}\left(\mathrm{Al}_{\mathrm{o}}\right.$, $\mathrm{Fe}_{\mathrm{o}}, \mathrm{Si}_{\mathrm{o}}$ ) following the procedures of Mehra and Jackson (1960) and Schwertmann (1964), respectively (Schlichting et al., 1995). The element concentrations in solutions were determined by ICP-OES. All basic soil analyses were performed in two lab replicates.

\subsubsection{Water extractable $\mathrm{Si}\left(\mathrm{Si}_{\mathrm{H}_{2} \mathrm{O}}\right)$}

Water extractable $\mathrm{Si}$ was determined by the method of Schachtschabel and Heinemann (1967). Ten grams of dry soil $(<2 \mathrm{~mm})$ were weighted into $80 \mathrm{~mL}$ plastic centrifuge tubes and $50 \mathrm{~mL}$ distilled water added together with three drops of a $0.1 \% \mathrm{NaN}_{3}$-solution to prevent microbial activity. The total extraction lasted seven days in which tubes were shaken by hand twice a day. Tubes were not shaken mechanically to avoid abrasion of coarse mineral particles colliding during shaking (Mc Keague and Cline, 1963). Finally the extraction solution was centrifuged (4000 rpm, $20 \mathrm{~min}$ ), filtrated $(0.45 \mu \mathrm{m}$ polyamide membrane filters) and $\mathrm{Si}$ was measured by ICP-OES. Analyses were performed in three lab replicates.

\subsubsection{Tiron extractable $\mathrm{Si}\left(\mathrm{Si}_{\text {Tiron }}\right)$}

The Tiron $\left(\mathrm{C}_{6} \mathrm{H}_{4} \mathrm{Na}_{2} \mathrm{O}_{8} \mathrm{~S}_{2 *} \mathrm{H}_{2} \mathrm{O}\right)$ extraction procedure was developed by Biermans and Baert (1977) and modified by Kodama and Ross (1991). It has been used to quantify amorphous biogenic and pedogenic Si, so-called "pedogenic silica" (Kendrick and Graham, 2004), although a partial dissolution of primary minerals is well known (Kodama and Ross, 1991; Sauer et al., 2006). The extraction procedure is as follows: dilution of $31.42 \mathrm{~g}$ Tiron (ACROS Organics, Geel, Belgium) with $800 \mathrm{~mL}$ of distilled water, followed by addition of $100 \mathrm{ml}$ sodium carbonate solution $\left(5.3 \mathrm{~g} \mathrm{Na}_{2} \mathrm{CO}_{3}\right.$ in $100 \mathrm{~mL}$ distilled water) under constant stirring. After that the $\mathrm{pH}$ of the solution increases from 3.3 to 7.5. Finally, the $\mathrm{pH}$ is brought to 10.5 by adding small volumes of a $4 \mathrm{M} \mathrm{NaOH}-$ solution. The Tiron solution is transferred into a $1 \mathrm{~L}$ volumetric flask and has a final concentration of $0.1 \mathrm{M}$. For the extraction $30 \mathrm{mg}$ of dry soil is weighted into $80 \mathrm{~mL}$ centrifuge tubes and a $30 \mathrm{~mL}$ aliquot of the Tiron solution added. The tubes are then heated at $80^{\circ} \mathrm{C}$ in a water bath for $1 \mathrm{~h}$. After cooling adhering water on the surface of the tubes is removed, the tubes are weighted and water lost by evaporation is replaced. The extracted solutions were centrifuged at 
$4000 \mathrm{rpm}$ for $30 \mathrm{~min}$, filtrated $(0.45 \mu \mathrm{m}$ polyamide membrane filters, Whatman NL 17) and elements were measured by ICP-OES. Analyses were performed in three lab replicates.

\subsubsection{Mineralogy, micromorphology and SEM-EDX analysis}

Powder samples of each soil horizon ( $<2 \mathrm{~mm}$ fraction) were analysed for basic mineral composition using a BRUCKER AXS D5000 Diffractometer ( $\mathrm{Cu}-\mathrm{K} \alpha$ radiation). The relative intensities of the diffraction maxima were used for a semiquantitative estimation of the concentration of mineral species present. The counts from the main reflection peak of all minerals were summed up and the relative proportion of each mineral was calculated as percent of the total. A subsample of the $<2 \mathrm{~mm}$ fraction was placed on an Alstub, fixed by adhesive tape, coated with minimal amount of gold-palladium and analysed on element composition by microprobe analysis (Hitachi S-2700 device, EDX-X-FlashDetector with SAMX-Software at ZELMI, TU-Berlin).

Four undisturbed soil samples (Kubiena boxes of $8 \mathrm{~cm}$ height) were taken from 0-8 cm (AE, Ah), 10-18 cm (AB), $44-52 \mathrm{~cm}\left(\mathrm{Bw}_{1}\right)$ and $104-112 \mathrm{~cm}(2 \mathrm{Cwt})$ (Fig. S2 in Supplement). Air-dried samples were impregnated with Leguval resin under vacuum. After hardening $24 \mu \mathrm{m}$ thick thin sections were prepared. The micromorphological features were described according to the concepts and terminology proposed by Stoops (2003). For thin section descriptions a SMLUX-POL (Leitz) microscope with polarisation filter was used. After description thin sections were coated with carbon in a vacuum evaporator, and then examined with electron microprobe analyses (Cameca Camebax Microbeam, ZELMI at TU Berlin), using an accelerating potential of $20 \mathrm{kV}$. Element distribution maps ( $\mathrm{Si}, \mathrm{Al}, \mathrm{Fe}, \mathrm{K}, \mathrm{Mg}, \mathrm{Ca}, \mathrm{Na}, \mathrm{Ti}$ ) were obtained with the same instrument. Feldspar grains and cutans (Fig. 5) were identified by microscopic examination on all thin sections (between 10 and 20 replicates, depending on the number of feldspar grains in each thin section). To obtain information about the weathering state of potassium feldspars, strewn slides of soil material from three different depths (10-20, 40-60, and 100-130 cm) were prepared and analysed using SEM (Fig. 6). For identification of feldspars, samples were analysed with REM-EDX and the potassium distribution in the slides was recorded. Each strewn slide was divided into four subsections and a minimum of ten replicates per subsection were analysed.

\subsubsection{Phytolith separation from plants and soils, SEM-EDX analysis}

Phytoliths were extracted from litterfall, the organic surface layer $(\mathrm{L})$ as well as from the first three mineral horizons (AE, $\mathrm{Ah}, \mathrm{AB}$ ). Litterfall from one sampling date (May to August 2008) was separated into four groups: leaves, bud scales, fruit capsules and wood from twigs and branches. The ex- traction procedure for litterfall was similar to soil horizons except steps 3 and 4 (see below). From each horizon $10 \mathrm{~g}$ of dry soil material $(<2 \mathrm{~mm})$ were processed in four steps (adapted from Alexandre et al., 1997). First organic matter is oxidized using $\mathrm{H}_{2} \mathrm{O}_{2}$ (35 Vol. \%), $\mathrm{HNO}_{3}\left(65 \mathrm{Vol} . \%\right.$ ), $\mathrm{HClO}_{4}$ $(70 \mathrm{Vol} . \%)$ at $80^{\circ} \mathrm{C}$ until reaction subsides. Secondly, carbonates and $\mathrm{Fe}$ oxides are dissolved by boiling the sample in $\mathrm{HCl}(10 \mathrm{Vol} . \%)$ for $30 \mathrm{~min}$. Thirdly, the $<2 \mu \mathrm{m}$ granulometric fraction is removed by dispersion of remaining solid phase of step 2 with 2 Vol. \% sodium hexametaphosphate solution $(6-12 \mathrm{~h})$, centrifugation at $1000 \mathrm{rpm}$ for $2-3 \mathrm{~min}$, and subsequent decantation. Finally, the phytoliths are separated by shaking the remaining solid phase of step 3 with $30 \mathrm{~mL}$ of sodium polytungstate $\mathrm{Na}_{6}\left(\mathrm{H}_{2} \mathrm{~W}_{12} \mathrm{O}_{40}\right) \cdot \mathrm{H}_{2} \mathrm{O}$ (density of $2.3 \mathrm{~g} \mathrm{~cm}^{-3}$ ), centrifugation at $3000 \mathrm{rpm}$ for $10 \mathrm{~min}$, carefully pipetting the supernatant, and filtering by $5 \mu \mathrm{m}$ teflon filter. This step was repeated three times. The filter residue was washed with water, bulked, dried at $105^{\circ} \mathrm{C}$, and weighted.

A subsample was placed on an Al-stub, fixed by adhesive tape, and coated with minimal amount of gold-palladium. Ten micrographs per stub were made using a JEOL JSM6060 LV SEM microscope $(500 \times$ magnification $)$. Phytoliths of each micrograph (coverage approx. $200 \times 200 \mu^{2}$ ) were counted. The database comprises a total number of 462 (L), 459 (AE), 422 (Ah), and 238 phytoliths (AB). They were described by shape according to ICPN (Madela et al., 2005) and assigned to vegetation (Golyeva, 2001) wherever applicable. Further, all counted phytoliths were assigned to one of three classes of phytolith dissolution: (i) plain phytoliths, (ii) phytoliths showing some surface etching, and (iii) phytoliths with strong dissolution features. Phytoliths at stubs were analysed on element composition by microprobe analysis (Hitachi S-2700 device, EDX-X-Flash-Detector with SAMX-Software at ZELMI, TU Berlin).

The Si pool of phytoliths was calculated assuming phytoliths to consist of pure $\mathrm{SiO}_{2}$. This results in a slight overestimation of the real Si pools, because biogenic opal contains ca. $10 \% \mathrm{H}_{2} \mathrm{O}$ and some accessory elements $(<1 \%)$ (Bartoli and Wilding, 1980).

\subsubsection{Plant analysis}

The collected plant litter (see Sect. 2.4) was oven dried at $105^{\circ} \mathrm{C}$ and milled in a planet type ball mill using milling vessels and balls made from $\mathrm{ZrO}_{2}$. Sample aliquots of approximately $200 \mathrm{mg}$ were digested under pressure in PFA digestion vessels using a mixture of $2.5 \mathrm{~mL} \mathrm{HNO}_{3}$ and $1 \mathrm{~mL} \mathrm{HF}$ at $220^{\circ} \mathrm{C}$ and approximately 100 bar (Ultra Clave II, MLS $\mathrm{GmbH}$, Leutkirch, Germany). Silicon was measured by ICPOES (Vista Pro, Varian Inc., Australia) using a HF-resistant sample introduction system, radial viewing of the plasma, and matrix matched external calibration. 


\subsubsection{Quantification of testate amoebae and related Si pool}

For testate amoebae analysis 5 field replicates $(20 \mathrm{~cm} \times 20 \mathrm{~cm})$ were placed randomly at Beerenbusch site avoiding areas close to stems (April 2011; Fig. S2 in Supplement). The litter layer (beech leaves) was removed and volumetric soil samples were taken in two segments: $0-2.5 \mathrm{~cm}$ and $2.5-5 \mathrm{~cm}$ (= sample volume of $1000 \mathrm{~cm}^{3}$ ). Aliquots of $2 \mathrm{~g}$ were taken for amoebae analysis in the field and stored in $8 \mathrm{~mL}$ formalin ( $4 \%$ aqueous formaldehyde solution). Total soil material of each depth increment and $20 \mathrm{~cm} \times 20 \mathrm{~cm}$ area was oven dried at $105^{\circ} \mathrm{C}$ and weighted. Bulk densities were calculated by dividing total soil mass by sample volume $\left(1000 \mathrm{~cm}^{3}\right)$. Testate amoebae were determined at species level and enumerated directly with an inverted microscope using stained (aniline blue) soil suspensions received from serial dilution (30-500 mg soil in $8 \mathrm{~mL}$ water per sample) as reported by Wanner (1999). Thereby living individuals and empty tests were distinguished. All species were assigned either to idiosomic or xenosomic amoebae taxa building up their tests from idiosomes (siliceous platelets synthesised by amoebae from $\mathrm{H}_{4} \mathrm{SiO}_{4}$ in soil solution) or xenosomes (extraneous materials such as mineral particles), respectively (e.g., Meisterfeld $2002 \mathrm{a}, \mathrm{b})$. Idiosomic Si pools $\left(\mathrm{g} \mathrm{m}^{-2}\right)$ of the upper $5 \mathrm{~cm}$ were calculated by (1) multiplying Si content of tests (Table 1 in Aoki et al., 2007) with counted individuals of each species, (2) multiplying these data with bulk densities and thickness $(2.5 \mathrm{~cm})$, and (3) finally summing up both depth increments.

\subsection{Site instrumentation for flux determinations}

The investigations of the study site water budget started in May 2001. The instrumentation as well as results of the first $4 \mathrm{yr}$ are described in Jochheim et al. (2007a). Precipitation was measured continuously at an open field located $500 \mathrm{~m}$ south of the study site using a heated rain gauge $(\mathrm{F} \& \mathrm{C} \mathrm{GmbH}$ Gülzow). Gaps in the precipitation data were filled by using open land precipitation data of either (i) the ICP Forests level II plot DE1202, or (ii) the weather station in Neuglobsow/Menz of the German Weather Service (DWD). For silicon analysis (started in May 2007) precipitation water of two rain samplers (RS200, UMS GmbH, Munich; $314 \mathrm{~cm}^{2}$ each) were collected weekly. Throughfall was measured continuously using a gutter of $0.8 \mathrm{~m}^{2}$ area with a tipping bucket rain gauge. Additionally, weekly measurements were carried out using 15 rain samplers (see above). Stemflow was measured continuously at one stem with a tipping bucket rain gauge, and additional weekly on 4 stems by sampling the water in barrels. For silicon analysis the weekly samples of open land precipitation, throughfall, and stemflow were bulked to monthly samples. Si concentrations in all waters were determined by ICP-OES.
Table 1. Mineralogical composition (wt.-\%) of soil horizons and sediment layers by semiquantative X-ray diffraction.

\begin{tabular}{lccc}
\hline Depth $(\mathrm{cm})$ & Quartz & Feldspar & Pyroxene \\
\hline $0-10$ & 97.1 & 2.5 & 0.4 \\
$10-20$ & 96.0 & 3.6 & 0.4 \\
$30-60$ & 97.7 & 1.8 & 0.5 \\
$60-80$ & 96.5 & 3.0 & 0.5 \\
$80-100$ & 93.0 & 6.6 & 0.4 \\
$100-130$ & 97.4 & 2.1 & 0.5 \\
$240-260$ & 97.4 & 2.6 & nd \\
$480-500$ & 98.0 & 2.0 & nd \\
\hline
\end{tabular}

nd $=$ not detected

Litterfall was collected in 8 inverted pyramidal litter traps $\left(0.25 \mathrm{~m}^{2}\right.$ each) bi-weekly during four years $(05 / 2006$ 04/2010) and separated into leaves, flowers, bud scales, beechnuts, fruit capsules, and wood from twigs and branches. Each fraction was bulked into three periods per year (Jan-Apr, May-Aug, Sep-Dec). For silicon analysis see Sect. 2.3.5.

Soil solution was sampled using borosilicate suction probes (EcoTech Bonn $\mathrm{GmbH}$ ) from 20, 70, and $250 \mathrm{~cm}$ soil depths (mean of $150 \mathrm{~cm}$ and $250 \mathrm{~cm}$ distance to stem; 4 replicates per depth and distance). The samples were collected by applying a suction of $-30 \mathrm{kPa}$ in 20 and $70 \mathrm{~cm}$, and $-35 \mathrm{kPa}$ in $250 \mathrm{~cm}$. Water was stored within the shafts of the suction probes and sampled bi-weekly. For silicon analysis the 4 field replicates per depth and distance were bulked. Si in soil water was measured by ICP-OES.

Analysis of water content was conducted hourly at different distances to stem $(50,150,250 \mathrm{~cm})$ of one stem in soil depths 20, 70, and 250 using Theta-probes ML2 (DeltaT Devices Ltd Cambridge, UK). Additionally, close to two further trees using identical distances to stem soil moisture were measured bi-weekly using TDR-probes (FOM/m-TDR, EasyTest Lublin, Poland) at identical soil depths.

Xylem sap flux was measured continuously during the vegetation periods of 2002-2005 on ten selected trees in $1.3 \mathrm{~m}$ tree height using the method after Granier (1985) and calculated to representative stand canopy transpiration following Lüttschwager and Remus (2007).

Aboveground woody tree biomass and forest growth were calculated by measuring stem diameter at breast height and tree height of all 108 trees of the plot in spring of 2006, 2008, and 2010 using form factors derived from the beech yield table (Dittmar et al., 1986), wood density (Trendelenburg and Mayer-Wegelin, 1955), bark density (Dietz, 1975), and bark fractions (Altherr et al., 1974).

\subsection{Calculation and modeling of Si fluxes}

Deposition of Si was calculated from the open land precipitation. Si fluxes were calculated by multiplying water fluxes 
with Si concentrations. Stand precipitation equals the sum of Si fluxes in throughfall and stemflow, whereas leaching from canopy is the difference of Si fluxes in stand precipitation and open land precipitation. Silicon uptake equals the sum of Si fluxes in litter fall, leaching from canopy, and wood increment. Si export through harvest was calculated as a sum of current accumulation of $\mathrm{Si}$ in stem wood including bark.

The simulation of water budget was carried out with the dynamic model Biome-BGC (version ZALF; Jochheim et al., 2007b; Puhlmann and Jochheim, 2007) which is based on Biome-BGC (Thornton et al., 2002). The model runs in daily time steps. It was re-calibrated and validated on the basis of data from intensive forest monitoring sites (Jochheim et al., 2009) as well as on forest yield tables. For this application the model was calibrated based on the measurements of the stand started in 2001. Silicon fluxes with drainage water were calculated for four years $(05 / 2007-04 / 2011)$ by multiplying the Si concentrations in soil water from suction probes with simulated soil water fluxes. Vertical distribution of passive Si uptake in soil was estimated from vertical distributed soil water uptake rates multiplied by Si concentrations in soil water. As the Si concentrations in soil water were analyzed in 3 soil depths only $(20,70,250 \mathrm{~cm})$, they were extrapolated to all other soil depths using the vertical distribution of water extractable Si.

\section{Results}

\subsection{Basic soil properties and soil mineralogy}

The studied soil is very sandy showing a sand content $>85 \%$ and a dominance of medium sand fraction $(0.2-0.63 \mathrm{~mm}$, Fig. 1). In the upper $50 \mathrm{~cm}$ a slight increase in silt can be observed. Clay content is always below $3 \%$ with slightly higher values in the upper $1.5 \mathrm{~m}$. The soil is decalcified down to a depth of $1.8 \mathrm{~m}$ (Fig. 1). Acidification leads to $\mathrm{pH}$ values between 4.3 and 4.5 in the upper $1.6 \mathrm{~m}$. Below that depth $\mathrm{pH}$ increases to $>7.0$ due to carbonatic sediments $(2-4 \%$ $\mathrm{CaCO}_{3}$ ). Quartz is the dominant mineral throughout the soil horizons and sediment layers (Table 1). Only minor additions of feldspars (orthoclase $>$ plagioclase), pyroxene and calcite occurred. Organically complexed $\mathrm{Fe}, \mathrm{Al}$ and pedogenic oxides $(\mathrm{Fe}, \mathrm{Al})$ decreased from $\mathrm{C}$-enriched surface horizons (upper $20 \mathrm{~cm}$ ) to subsoil horizons as crystallinity of iron oxides increased $\left(\mathrm{Fe}_{o}: \mathrm{Fe}_{\mathrm{d}} 0.6 \rightarrow 0.2\right)$. The molar $\mathrm{Si} / \mathrm{Al}$ ratios in oxalate extracts $\left(\mathrm{Si}_{\mathrm{O}}: \mathrm{Al}_{\mathrm{o}}\right)$ remained below 0.3 in all soil horizons rendering neoformation of short-range order minerals, like allophane or imogolite ( $\mathrm{Si} / \mathrm{Al} \approx 0.5$ ), hardly probable.

\subsection{Si pools in soils}

Water soluble Si shows a decrease from $16 \mathrm{mg} \mathrm{kg}^{-1}$ in the upper $2 \mathrm{~cm}$ to $4 \mathrm{mg} \mathrm{kg}^{-1}$ in subsoil horizons and a recurring increase in sediments containing carbonates (Fig. 1).
The water-soluble Si pool down to $2.8 \mathrm{~m}$ equals $21 \mathrm{~g} \mathrm{Si} \mathrm{m}^{-2}$ $\left(=210 \mathrm{~kg} \mathrm{Si} \mathrm{ha}^{-1}\right)$. The uppermost meter contains $6 \mathrm{~g} \mathrm{Si} \mathrm{m}^{-2}$ $\left(=60 \mathrm{~kg} \mathrm{Si} \mathrm{ha}^{-1}\right)$.

Tiron extractable Si is three orders of magnitude higher compared to water soluble $\mathrm{Si}$. The depth function of Tiron extractable $\mathrm{Si}$ shows a continuous decrease from $3 \mathrm{~g} \mathrm{~kg}^{-1}$ in topsoil horizons to $<2 \mathrm{~g} \mathrm{~kg}^{-1}$ in deepest sediments. The highest $\mathrm{Si}$ content can be observed in the uppermost horizon (AE). The Tiron extractable Si pool down to $2.8 \mathrm{~m}$ equals $10 \mathrm{~kg} \mathrm{Si} \mathrm{m}^{-2}\left(=100 \mathrm{Mg} \mathrm{Si} \mathrm{ha}^{-1}\right)$. The uppermost meter contains $4 \mathrm{~kg} \mathrm{Si} \mathrm{m}^{-2}\left(=40 \mathrm{Mg} \mathrm{Si} \mathrm{ha}^{-1}\right)$.

\subsubsection{Phytogenic Si pool in soil}

Phytolith contents decrease from litter to mineral soil horizons by one order of magnitude (Table 2a). The upper $20 \mathrm{~cm}$ of the soil contain $140 \mathrm{~g}$ phytoliths m $\mathrm{m}^{-2}\left(=1400 \mathrm{~kg} \mathrm{ha}^{-1}\right)$. Assuming all phytoliths to consist of pure $\mathrm{SiO}_{2}$ (EDX spectra in Fig. 2c) we calculated $66 \mathrm{~g} \mathrm{Si} \mathrm{m}^{-2}$ for the phytolith Si pool in the upper $20 \mathrm{~cm}\left(=660 \mathrm{~kg} \mathrm{Si} \mathrm{ha}^{-1}\right)$. This simplification results in a slight overestimation of the true phytogenic Si pool as biogenic opal contains approx. $10 \% \mathrm{H}_{2} \mathrm{O}$ and some accessory elements $(<1 \%)$ (Bartoli and Wilding, 1980).

The phytolith assemblage of soil horizons - as assignable by shape (ICPN, Madella et al., 2005) - is dominated by elongate (polylobate, fusiform) and short-cell phytoliths (bilobate, trapeziform) with minor contribution of globular and vascular phytoliths. In terms of vegetation a dominance of grass phytoliths were found in mineral soil horizons below $2 \mathrm{~cm}$ (Table 2b, Fig. 2b). This fits very well to the vegetation survey from 1954 which showed plants high in $\mathrm{Si}$, such as Calamagrostis epigejos $(2.2 \% \mathrm{Si})$, Brachypodium sylvaticum $(3.1 \% \mathrm{Si})$, and Agrostis capillaris $(1.4 \%$ $\mathrm{Si}$ ), dominating the ground vegetation (Table S6 in Supplement, Si data from Hodson et al., 2005). Pine and moss phytoliths (rounded particles, Al-rich) can be identified as well (Table 2b, Fig. 2b). However, as there are no more pine and grasses growing at the study site (at least for the last $30 \mathrm{yr}$ ) pine and grass phytoliths extracted from the soil represent a relictic biogenic Si pool. Surprisingly, clearly identifiable beech phytoliths only account for a minor portion in the upper centimeters. Further, those forms isolated from litterfall (Fig. 2a) are hardly detectable in their original shape in the soil, even not in the upper $2 \mathrm{~cm}$ (Fig. 2b). From these findings either a rapid mechanical destruction or a preferential dissolution of beech phytoliths can be concluded. Nevertheless, one has to recognize that $50-75 \%$ of all phytoliths counted cannot be assigned to any vegetation throughout the uppermost $20 \mathrm{~cm}$ of the soil (Table $2 \mathrm{~b}$ ).

\subsubsection{Zoogenic Si pool in soil}

A total number of $6.1 \times 10^{8} \mathrm{~m}^{-2}$ testate amoebae $(60 \%$ living individuals) was determined in the upper $5 \mathrm{~cm}$ of the soil. This number lies in the range of published data (e.g., 

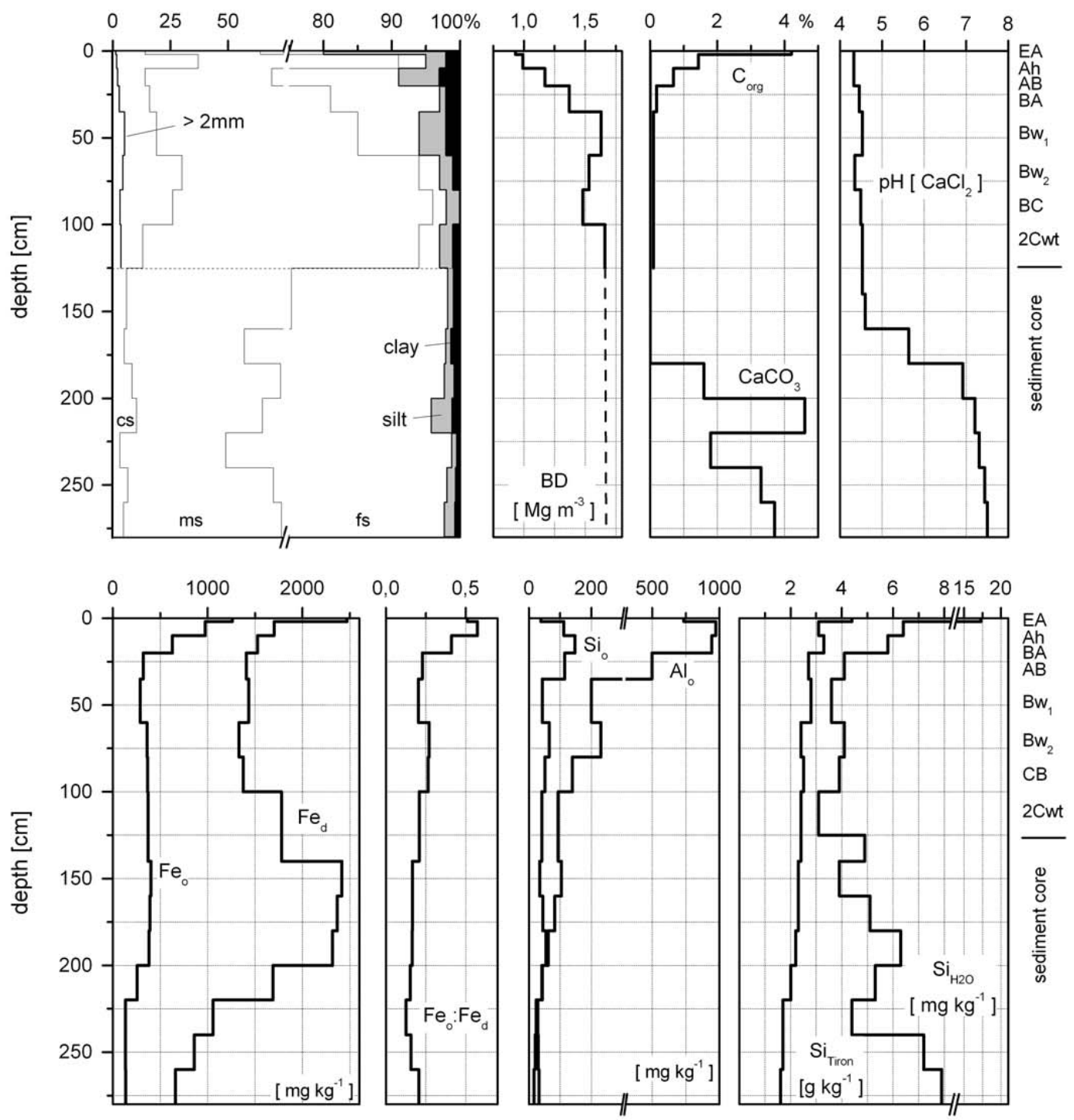

Fig. 1. Depth functions of basic soil properties from the Brunic Arenosol (Dystric).

Aoki et al., 2007; Ehrmann et al., 2012; Wanner and Dunger, 2001). Approximately $50 \%$ of all individuals (living and empty tests) belong to either idiosomic or xenosomic taxa of testate amoebae. Xenosomic taxa build up their tests from extraneous materials such as mineral soil particles. Dominant xenosomic taxa at our site are Phryganella acropodia, Plagiopyxis declivis, and Centropyxis sphagnicola (Fig. 3d). Dominant idiosomic taxa embrace Trinema complanatum, Euglypha rotunda, and Trinema lineare (Fig. 3a-c). Only idiosomic taxa can be regarded as a biogenic Si pool influencing dissolved $\mathrm{Si}$ (DSi), because they synthesise siliceous platelets for their tests from silica of the soil solution (Anderson, 1994). Therefore, we calculated the zoogenic Si pool only on basis of idiosome-producing amoebae and came up with $0.19 \mathrm{~g} \mathrm{Si} \mathrm{m}^{-2}$ in the upper $5 \mathrm{~cm}$ of the soil (=1.9 $\mathrm{kg} \mathrm{Si} \mathrm{ha}^{-1}$, Table 3$)$. Compared to soil's phytolith $\mathrm{Si}$ pool as derived from density separation, these numbers are two orders of magnitude lower.

\subsection{Si in aboveground plant biomass}

Beech leaves showed the highest Si concentrations followed by bark of branch and stem wood, bud scales, and fruit capsules (Table 4). Beechnuts and woody biomass without bark contain the lowest $\mathrm{Si}$ concentrations. Interannual variations in Si concentrations are largest in leaves, bud scales, and fruit capsules. In 2006 lowest Si concentrations in leaves were measured $\left(7 \mathrm{~g} \mathrm{~kg}^{-1}\right)$. In litterfall of $2007 \mathrm{Si}$ concentrations nearly doubled $\left(13.6 \mathrm{~g} \mathrm{~kg}^{-1}\right)$ which might be an effect of the length of growing period (dry summer in 2006). In terms of intra-annual variations a seasonal trend of $\mathrm{Si}$ concentrations can be observed: Si concentrations of leaves from early 
Table 2a. Phytoliths and related Si pools.

\begin{tabular}{|c|c|c|c|c|c|c|c|c|}
\hline & & $\begin{array}{l}\text { Depth } \\
(\mathrm{cm})\end{array}$ & $\begin{array}{c}\text { Bulk } \\
\text { density } \\
\left(\mathrm{Mg} \mathrm{m}^{-3}\right)\end{array}$ & $\begin{array}{l}\text { Phytolith } \\
\left(\mathrm{g} \mathrm{kg}^{-1}\right)\end{array}$ & $\begin{array}{l}\text { Phytolith } \\
\left(\mathrm{g} \mathrm{m}^{-2}\right)\end{array}$ & $\begin{array}{c}\mathrm{Si} \\
\text { content } \\
\left(\mathrm{g} \mathrm{kg}^{-1}\right)\end{array}$ & $\begin{array}{l}\text { Phytolith } \mathrm{Si} \text {, } \\
\text { calculated } \\
\left(\mathrm{g} \mathrm{kg}^{-1}\right)\end{array}$ & $\begin{array}{c}\text { Phytolith } \mathrm{Si} \text {, } \\
\text { calculated } \\
\left(\mathrm{g} \mathrm{m}^{-2}\right)\end{array}$ \\
\hline Litterfall & leaves & - & & 5.1 & - & 4.4 & 2.4 & - \\
\hline \multirow{3}{*}{$(5-8 / 08)$} & bud scales & - & & 7.0 & - & 3.6 & 3.3 & - \\
\hline & fruit capsules & - & & 1.1 & - & 1.1 & 0.5 & - \\
\hline & branches & - & & 1.0 & - & 1.4 & 0.5 & - \\
\hline \multirow[t]{5}{*}{ Soil } & litter layer (L) & & & 8.7 & & & 4.1 & \\
\hline & $\mathrm{AE}$ & $0-2$ & 0.92 & 0.9 & 17 & & 0.4 & 8 \\
\hline & $\mathrm{Ah}$ & $2-10$ & 0.99 & 1.2 & 92 & & 0.5 & 43 \\
\hline & $\mathrm{AB}$ & $10-20$ & 1.17 & 0.3 & 32 & & 0.1 & 15 \\
\hline & sum & $0-20$ & & & 140 & & & 66 \\
\hline
\end{tabular}

Table 2b. Morphological description and identification of phytoliths; n.a. = not assignable.

\begin{tabular}{|c|c|c|c|c|c|c|c|c|c|c|c|}
\hline \multirow{2}{*}{$\begin{array}{l}\text { Soil } \\
\text { Horizon }\end{array}$} & \multirow{2}{*}{$\begin{array}{l}\text { Depth } \\
(\mathrm{cm})\end{array}$} & \multicolumn{10}{|c|}{ Count- $\%$ of total phytolith number (10 SEM micrographs) } \\
\hline & & Globular & Elongate & Short cell & Vascular & n.a. & Grasses & Beech & Mosses & Pine & n.a. \\
\hline Litter layer (L) & & 7 & 25 & 18 & 1 & 49 & 7 & 12 & 4 & 1 & 75 \\
\hline $\mathrm{AE}$ & $0-2$ & 7 & 25 & 20 & 2 & 45 & 16 & 5 & 5 & 3 & 72 \\
\hline $\mathrm{Ah}$ & $2-10$ & 0 & 38 & 15 & 0 & 47 & 44 & 0 & 1 & 2 & 53 \\
\hline $\mathrm{AB}$ & $10-20$ & 0 & 27 & 8 & 0 & 64 & 45 & 0 & 0 & 1 & 54 \\
\hline
\end{tabular}

Table 3. Si pools of idiosomic testate amoebae; mean values and standard deviation (in brackets), $n=5$ field replicates.

\begin{tabular}{lllll}
\hline $\begin{array}{l}\text { Depth } \\
(\mathrm{cm})\end{array}$ & $\begin{array}{l}\text { Bulk density } \\
\left(\mathrm{Mg} \mathrm{m}^{-3}\right)\end{array}$ & $\begin{array}{l}\text { Living } \\
\mathrm{mg} \mathrm{Si} \mathrm{m}^{-2}\end{array}$ & $\begin{array}{l}\text { Empty shells } \\
\mathrm{mg} \mathrm{Si} \mathrm{m}^{-2}\end{array}$ & $\begin{array}{l}\text { Total } \\
\mathrm{mg} \mathrm{Si} \mathrm{m}^{-2}\end{array}$ \\
\hline $0-2.5$ & $0.10(0.04)$ & $81(110)$ & $54(48)$ & $135(158)$ \\
$2.5-5$ & $0.36(0.11)$ & $34(25)$ & $22(11)$ & $57(23)$ \\
sum 0-5 & & $116(106)$ & $76(43)$ & $192(148)$ \\
\hline
\end{tabular}

stages of vegetation development (May-Aug) were lowest (4.4-6.8 $\mathrm{g} \mathrm{kg}^{-1}$ ), whereas during autumn/winter (Sep-Dec) or winter/spring (Jan-Apr) Si concentrations range from 6 to $14 \mathrm{~g} \mathrm{~kg}^{-1}$ (depending on single year).

Taking into account the biomass of each plant compartment the total $\mathrm{Si}$ pool in aboveground biomass summarises up to $83 \mathrm{~kg} \mathrm{Si} \mathrm{ha}^{-1}$ (Table 4 ). The stem bark contributes the largest fraction $(50 \%)$ followed by leaves $(36 \%)$, branch bark $(6 \%)$, and stem wood $(3 \%)$.

\subsection{Internal and external Si fluxes}

Si uptake by plants contributes the largest internal Si flux in the biogeosystem ( $35 \mathrm{~kg} \mathrm{Si} \mathrm{ha}^{-1} \mathrm{yr}^{-1}$, Fig. 4). The major part is transported into the leaves $\left(30 \mathrm{~kg} \mathrm{Si} \mathrm{ha}^{-1} \mathrm{yr}^{-1}\right)$ rendering autumn litter fall the most important annual flux component to the soil. Minor fluxes are related to annual litterfall of twigs, bud scales, fruits, and flowers $\left(4 \mathrm{~kg} \mathrm{Si} \mathrm{ha}^{-1} \mathrm{yr}^{-1}\right)$ or dendromass increments $\left(0.7 \mathrm{~kg} \mathrm{Si} \mathrm{ha}^{-1} \mathrm{yr}^{-1}\right)$. Although the Si pool size of testate amoebae is very small their relevance for internal Si cycling cannot be neglected. Due to relatively short generation times of idiosome-producing amoebae, e.g., Euglyphida with 2-16 days resulting in 12-130 generations per year (Schönborn, 1975, 1982; Lousier, 1984; Aoki et al., 2007), the annual biosilicification by idiosomes are in the order of the cumulative annual Si uptake by plants: using a conservative estimate of 15 generations per year we calculated an annual biosilicification of $17 \mathrm{~kg} \mathrm{Si} \mathrm{ha}^{-1} \mathrm{yr}^{-1}(\mathrm{Si}$ pool of living idiosomic taxa). The turnover rates of idiosomic Si pool must be much higher compared to phytolithic Si pool as can be deduced from (only) $47 \%$ empty tests of total idiosomic Si pool. Consequently, testate amoebae can be regarded as a temporal $\mathrm{Si}$ pool on a very short, monthly timescale.

The total $\mathrm{Si}$ input with open land precipitation is rather low $\left(<1 \mathrm{~kg} \mathrm{Si} \mathrm{ha}^{-1} \mathrm{yr}^{-1}\right)$ which fits to the data from literature (Sommer et al., 2006; Cornelis et al., 2011b). The Si export by seepage equals $12 \mathrm{~kg} \mathrm{Si} \mathrm{ha}^{-1} \mathrm{yr}^{-1}$ showing average silica concentrations of approx. $6 \mathrm{mg} \mathrm{Si} \mathrm{L}^{-1}$ (Table 5). The high temporal variability between years $(\mathrm{CV}=50-64 \%)$ can be related to varying seepage (Table 5), while temporal variability in silica concentrations were rather small (CV increase with depth: $4 \rightarrow 11 \%$ ). Mean silica concentration increases only slightly from acid soil horizons $(0.2 \mathrm{~m}, 0.7 \mathrm{~m})$ to the calcareous parent material in $2.5 \mathrm{~m}\left(4.9 \rightarrow 5.7 \mathrm{mg} \mathrm{Si} \mathrm{L}^{-1}\right.$, 
Table 4. Pools and increments of plant biomass, Si concentrations (mass weighted mean values), Si pools in aboveground biomass, Si fluxes with increment of tree biomass; *: calculated from litter fall of 05/2006-04/2010; **: calculated from stem volume of 2010 or stem growth of 2006-2009; no. in brackets $=$ std.dev. $(n=4 \mathrm{yr})$.

\begin{tabular}{llllll}
\hline & $\begin{array}{l}\text { Biomass } \\
\text { pools } \\
(\mathrm{t} \mathrm{DM} \mathrm{ha}\end{array}$ & $\begin{array}{l}\text { Litterfall/ } \\
\text { increment } \\
\left(\mathrm{t} \mathrm{DM} \mathrm{ha}^{-1} \mathrm{yr}^{-1}\right)\end{array}$ & Si content & Si pools & Si fluxes \\
\hline Leaves* & 3.4 & $3.4(0.30)$ & $8952(3101)$ & 29.7 & $29.7(7.5)$ \\
Bud scales* & 0.5 & $0.5(0.04)$ & $2395(431)$ & 1.2 & $1.2(0.3)$ \\
Beechnuts* & 0.7 & $0.7(0.80)$ & $280(252)$ & 0.2 & $0.2(0.3)$ \\
Fruit capsules* & 1.6 & $1.6(1.20)$ & $913(275)$ & 1.4 & $1.4(1.1)$ \\
Other* & & $0.1(0.03)$ & $10229(2979)$ & $0.6(0.4)$ \\
Branches/twigs including bark* & & $0.4(0.30)$ & $1649(183)$ & $0.7(0.5)$ \\
\hline Total litterfall & & 6.7 & & 33.7 \\
\hline Branch wood without bark** & 24.4 & 0.4 & 17 & 0.4 & 0.01 \\
Stem wood without bark** & 196.1 & 3.1 & 2565 & 3.4 & 0.05 \\
Bark of branch wood** & 2.0 & 0.0 & 2565 & 41.9 & 0.08 \\
Bark of stem wood** & 16.3 & 0.2 & & & 0.59 \\
Dendromass increment & & 3.7 & & 83.4 & 0.70 \\
\hline Aboveground biomass & 245.0 & & & & 3.2 \\
\hline
\end{tabular}

Table 5). This increase goes along with an increase in the water-soluble Si fraction (Fig. 1).

We set the annual accumulation rate of $\mathrm{Si}$ in stem wood and bark $\left(0.6 \mathrm{~kg} \mathrm{Si} \mathrm{ha}^{-1} \mathrm{yr}^{-1}\right)$ as the (annual) harvest export. Although not realized yet, at the end of a rotation period stem harvest leads to a complete Si export of this compartment. By adding this Si export to seepage losses we come up with a gross Si loss of $13 \mathrm{~kg} \mathrm{Si} \mathrm{ha}^{-1} \mathrm{yr}^{-1}$. Taking into account the inputs by deposition our biogeosystem reveals a net loss of $12 \mathrm{~kg} \mathrm{Si} \mathrm{ha}^{-1} \mathrm{yr}^{-1}$.

\section{Discussion}

The low atmospheric Si input is in accordance with reported values from other forested biogeosystems $\left(<2 \mathrm{~kg} \mathrm{ha}^{-1} \mathrm{yr}^{-1}\right.$, Sommer et al., 2006; Cornelis et al., 2011b). Throughfall and stemflow can also be neglected in terms of Si fluxes. The small annual increase in $\mathrm{Si}$ stored in the vegetation (biomass increment $=0.7 \mathrm{~kg} \mathrm{Si} \mathrm{ha}^{-1} \mathrm{yr}^{-1}$ ) is lower compared to reported data (European beech $=3.5 \mathrm{~kg} \mathrm{Si} \mathrm{ha}^{-1} \mathrm{yr}^{-1}$, Cornelis et al., 2010a) which might be explained by the lower forest growth of our mature beech stand (120 yr). The Si uptake by beech $\left(35 \mathrm{~kg} \mathrm{Si} \mathrm{ha}^{-1} \mathrm{yr}^{-1}\right)$ and return flux by litterfall $\left(34 \mathrm{~kg} \mathrm{Si} \mathrm{ha}^{-1} \mathrm{yr}^{-1}\right)$ lies in the range of other European beech stands in temperate climates (19-47 kg Si ha ${ }^{-1} \mathrm{yr}^{-1}$ : Pavlov, 1972; Bartoli and Souchier, 1978; Ellenberg et al., 1986; Cornelis et al., 2010a). We calculated an averaged passive Si-uptake of $17 \mathrm{~kg} \mathrm{Si} \mathrm{ha}^{-1} \mathrm{yr}^{-1}$ as the product of vertically distributed mean $\mathrm{Si}$ concentrations and modeled transpiration flux $\left(239 \mathrm{~mm} \mathrm{yr}^{-1}\right)$. When compared to the measured
Table 5. Water fluxes, $\mathrm{Si}$ concentrations, and $\mathrm{Si}$ fluxes in water $(\mathrm{m}=$ measurements, $\mathrm{s}=$ simulation $)$; all fluxes are expressed as mean annual values for a four year period (5/2007-4/2011), number in brackets $=\operatorname{std} . \operatorname{dev}(n=4 \mathrm{yr})$.

\begin{tabular}{llll}
\hline & $\begin{array}{l}\text { Water flux } \\
\left(\mathrm{L} \mathrm{m}^{-2} \mathrm{yr}^{-1}\right)\end{array}$ & $\begin{array}{l}\text { Si concentr. } \\
\left(\mathrm{mg} \mathrm{L}^{-1}\right)\end{array}$ & $\begin{array}{l}\text { Si flux } \\
\left(\mathrm{kg} \mathrm{ha}^{-1} \mathrm{yr}^{-1}\right)\end{array}$ \\
\hline $\begin{array}{l}\text { Precipitation (m) } \\
\text { Leaching from canopy (m) }\end{array}$ & $689(195)$ & $0.1(0.03)$ & $0.6(0.2)$ \\
Canopy evaporation (s) & $168(28)$ & & $0.3(0.1)$ \\
Transpiration (s) & $239(24)$ & & \\
Evapotranspiration (s) & $476(62)$ & & $0.8(0.3)$ \\
Throughfall (m) & $491(189)$ & $0.1(0.04)$ & $0.1(0.0)$ \\
Stemflow (m) & $32(13)$ & $0.3(0.03)$ & $0.9(0.3)$ \\
Stand precipitation (m) & $523(203)$ & & $15.4(7.6)$ \\
Drainage from $20 \mathrm{~cm}(\mathrm{~s})$ & $316(152)$ & $4.9(0.20)$ & $13.9(8.0)$ \\
Drainage from 70 cm (s) & $262(139)$ & $5.3(0.30)$ & $\mathbf{1 2 . 3 ( 7 . 9 )}$ \\
\hline Drainage from $\mathbf{2 5 0} \mathbf{~ c m ~ ( s ) ~}$ & $\mathbf{2 1 4 ( 1 3 3 )}$ & $\mathbf{5 . 7}(\mathbf{0 . 6 0})$ & \\
\hline
\end{tabular}

Si-uptake of $34 \mathrm{~kg} \mathrm{Si} \mathrm{ha}^{-1} \mathrm{yr}^{-1}$ an active uptake of $50 \%$ of total uptake can be inferred.

Generally, the magnitude of Si uptake at Beerenbusch surprises, when considering the very low content of weatherable minerals in the rooting zone (soils, sediments). In principal three processes might cause the silica concentrations observed: (i) quartz dissolution, (ii) weathering of silicates, and (iii) dissolution of the biogenic Si pool (non-steady state).

\subsection{Quartz dissolution and silicate weathering}

Quartz has a water solubility of $1-7 \mathrm{mg} \mathrm{L}^{-1}$ (36$250 \mu \mathrm{mol} \mathrm{L}^{-1}$ ) depending on particle size and temperature (Iler, 1979; Bartoli and Wilding, 1980; Dove, 1995). The 
a
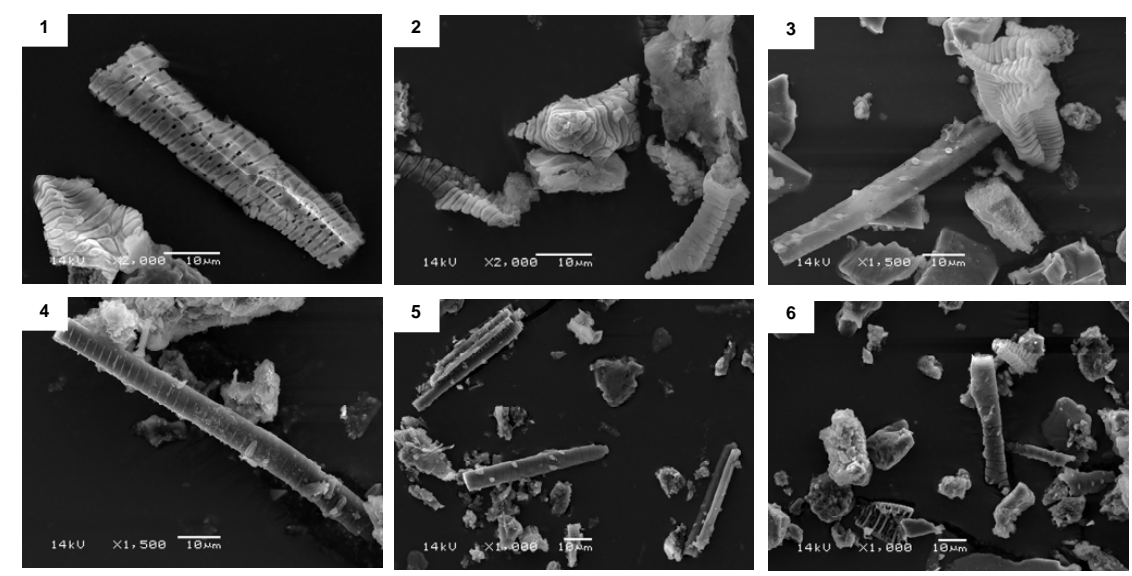

b

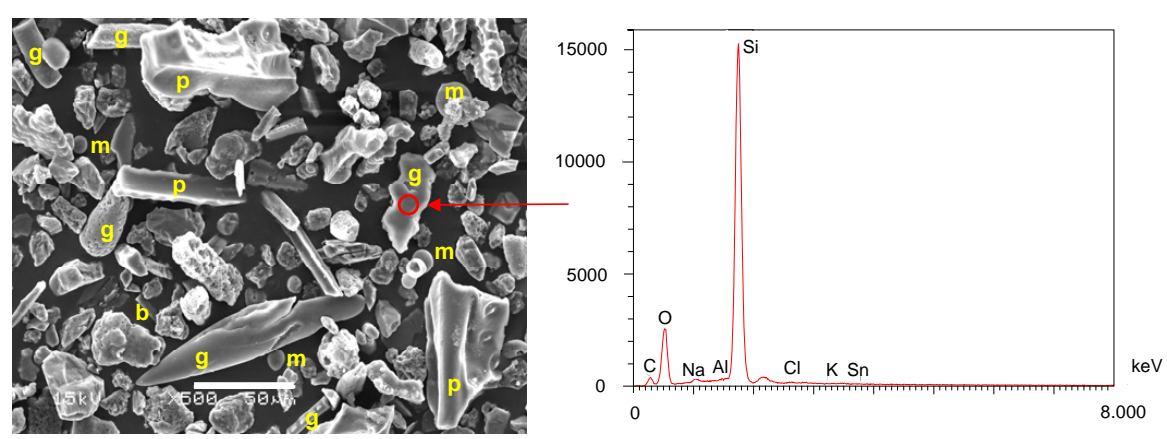

Fig. 2. (a) SEM micrographs of opal phytoliths in Fagus sylvatica litterfall (1, 2, 3 leaves, 4, 5 bud scales, 6 fruit capsules), scale bars at all micrographs $=10 \mu \mathrm{m}$; (b) SEM micrographs of opal phytoliths in AE horizon, $0-2 \mathrm{~cm}$, scale bar $=50 \mu \mathrm{m}(\mathrm{b}=\mathrm{beech}, \mathrm{p}=\mathrm{pine}, \mathrm{g}=\mathrm{grass}$, $\mathrm{m}=$ moss); (c) element distribution of a grass opal phytolith (SEM-EDX).
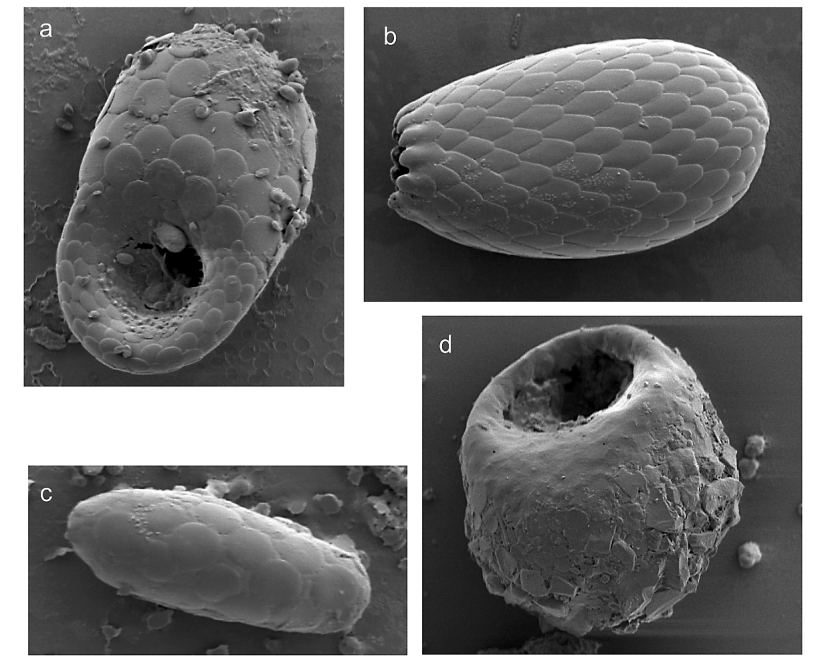

Fig. 3. SEM micrographs of dominant testate amoebae; idiosomic taxa: (a) Trinema complanatum (length $=46 \mu \mathrm{m})$, (b) Euglypha rotunda $($ length $=49 \mu \mathrm{m})$, (c) Trinema lineare (length $=23 \mu \mathrm{m})$; xenosomic taxa: (d) Centropyxis sphagnicola (length $=65 \mu \mathrm{m}$ ). lower value is more realistic for soils. This is supported by soil water data from quartz-rich, non-redoximorphic soils developed on quarzitic or granitic lithologies in the Black Forest (Podzols, Cambisols) showing silica concentrations always $<2.5 \mathrm{mg} \mathrm{L}^{-1}$ (Sommer et al., 2006). Studies from tropical soils with absolute quartz dominance also confirm low silica concentrations in soil waters $\left(<1.2 \mathrm{mg} \mathrm{Si} \mathrm{L}^{-1}\right.$ : Cornu et al., 1998; Lucas, 2001; Patel-Sorentino et al., 2007; do Nascimento et al., 2008).

There are two reasons for observed lower in situ silica concentrations compared to lab experiments on pure phases: (i) lab studies on quartz dissolution kinetics mostly use samples ground to silt size which leads to fresh mineral surfaces and high surface : volume ratios compared to our site showing sand as the dominating particle size class. (ii) Surface coatings (Fe oxides, organic matter) protect quartz grains from intense dissolution, because of the reduced access of soil solution to quartz surfaces. Chemical interactions between soil solution and solid phase mainly take place at the surface of coatings. The latter occur at all soil depths as depicted from thin sections (Fig. 5, upper). Coatings show dark to light brown colors and an average thickness 


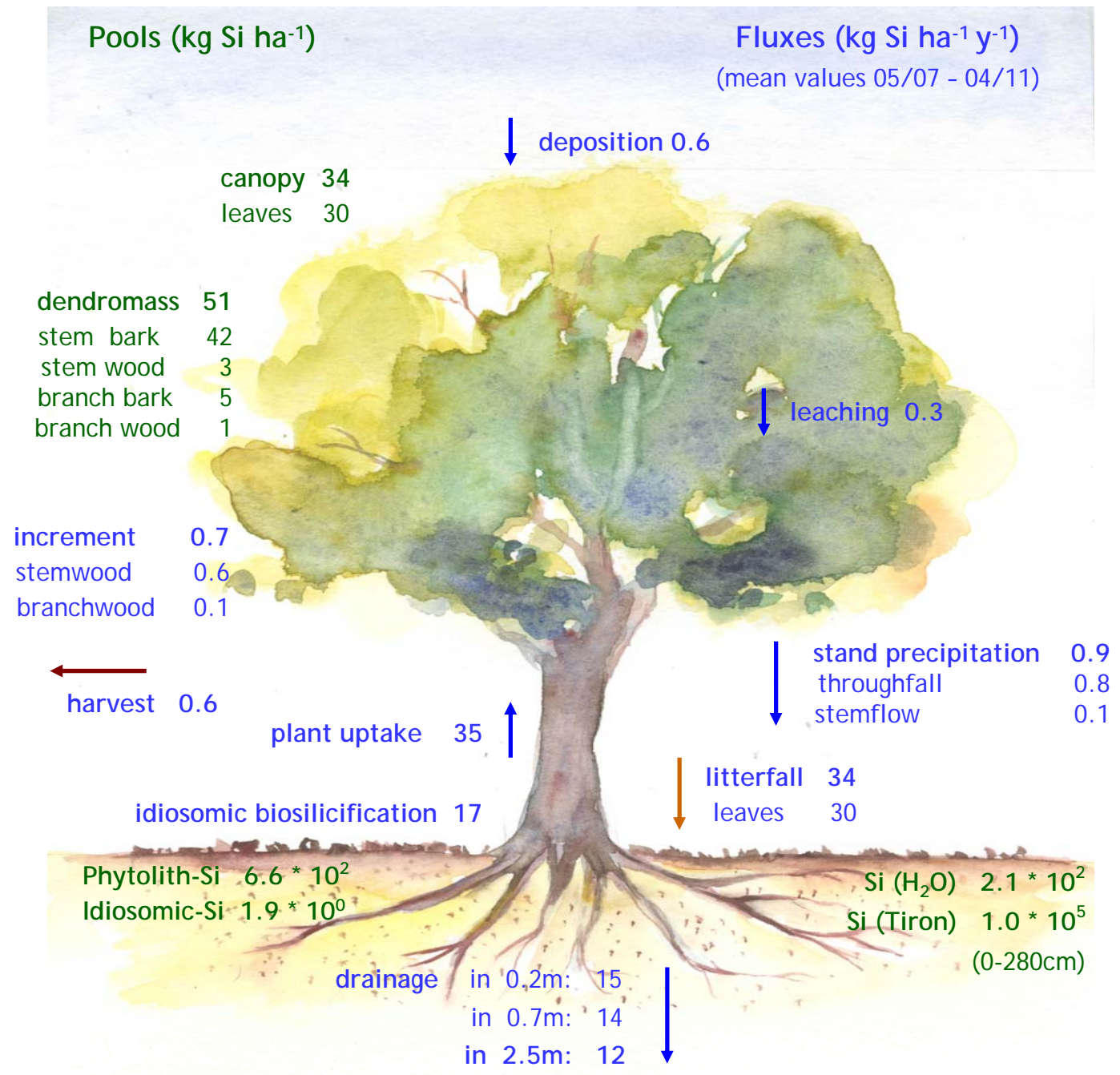

Painting: C. Höhn

Fig. 4. Si pools and fluxes at Beerenbusch (mean values 05/2007-04/2011) (painting: Cornelia Höhn, Müncheberg).

of 10-20 $\mu \mathrm{m}$. From element distribution (EDX analysis on several coatings, Fig. 5 lower) two different mineral phases can be inferred - an iron bearing oxyhydroxide, most probably goethite, and kaolinite. Subsoil horizons show a higher percentage of $\mathrm{Fe}$ in the coatings ("ferri-argillans", compare Chartres, 1987; Stoops, 2003; Li et al., 2008). Because feldspar and quartz coatings showed a similar chemical composition they cannot be interpreted as weathering rinds. Instead, a vertical redistribution of fine material by clay translocation (see macroscopic lamellae in $2 \mathrm{Cwt}$ ) and podzolization (precipitation of organic Fe-Al-complexes), combined with a $\mu \mathrm{m}$-scale horizontal redistribution of fines during desiccation (water films around grains) are the most probable explanations. From these findings we conclude that quartz dissolution will contribute only a minor fraction to the silica concentrations observed.
Weatherable silicates (mainly K-feldspars, few plagioclase) contribute $3 \%$ (average) to the mineral assemblage of our soil and sediments. Due to the low content and a higher stability of orthoclase, we expected a comparative low contribution of feldspar weathering to DSi. Nevertheless, we checked feldspar weathering intensity by thin sections and SEM. In thin sections some feldspars have been found as part of compact multimineral sand grains (Fig. S2 in Supplement), probably derived from glacier grinding of granites and subsequent glaciofluvial sorting processes. Here the accessible surface area for chemical weathering is very limited. Further, single feldspar grains appear only slightly weathered in SEM micrographs compared, e.g., to feldspars in White et al. (2008). Furthermore there is no trend with depth (Fig. 6). These findings are surprising, because the high input of organic acids by podzolization should enhance acid hydrolysis. 

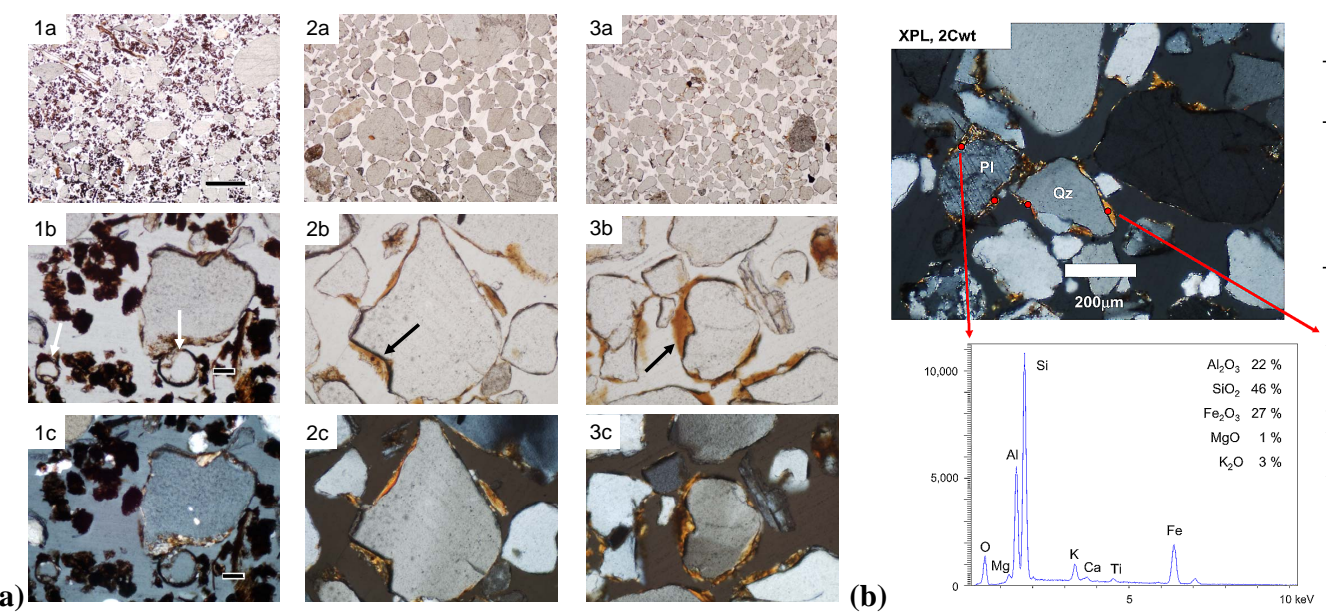

\begin{tabular}{rrrr}
\hline $\begin{array}{r}10-18 \mathrm{~cm} \\
(n=3)\end{array}$ & $\begin{array}{r}4-52 \mathrm{~cm} \\
(n=2)\end{array}$ & $\begin{array}{r}104-112 \mathrm{~cm} \\
(n=5)\end{array}$ \\
\hline $\mathrm{Al}_{2} \mathrm{O}_{3}$ & 30 & 22 & 23 \\
$\mathrm{SiO}_{2}$ & 47 & 45 & 46 \\
$\mathrm{Fe}_{2} \mathrm{O}_{3}$ & 18 & 28 & 25 \\
$\mathrm{MgO}$ & 1 & 1 & 2 \\
$\mathrm{~K}_{2} \mathrm{O}$ & 2 & 3 & 3 \\
\hline
\end{tabular}

Fig. 5. (a) Micromorphological properties of soil horizons; microstructure (a, b=PPL, c = XPL) of selected soil horizons: (1) AE (0-2 cm), arrows point to testate amoebae; (2) $\mathrm{Bw}_{1}(44-51 \mathrm{~cm})$, arrow points to Fe-oxides/clay coating; (3) 2 Cwt $(104-112 \mathrm{~cm})$, arrow points to Fe-oxides/clay coating; widths of photo: $1 \mathrm{a}, 2 \mathrm{a}, 3 \mathrm{a}=6 \mathrm{~mm}$; other $=0.6 \mathrm{~mm}$. (b) SEM-EDX micrographs of cutans in $2 \mathrm{Cwt}(104-112 \mathrm{~cm}$ ); average chemical composition (wt. $-\%$ ) of coatings of different depths analysed by electron microprobe; number in brackets = no. of cutans analysed by EDX in each thin section.

Coatings on feldspar grains (Fig. 5) most probably explain this apparent contradiction as coatings reduce accessability of soil water to feldspar surfaces, hence chemical reactions. Soil solution chemistry measured from 2001 to 2012 supports our SEM findings (mean concentrations at 20, 70, $250 \mathrm{~cm}$ in $\left.\mathrm{mg} \mathrm{L}^{-1}\right)$ : Neither $\mathrm{Na}(5.8,5.5,5.9)$ nor $\mathrm{Cl}(7.9,7.4$, 8.7) give evidence for a silicate weathering front. Instead, the depth trends of DOC (23.6, 15.1, 6.7 $\left.\mathrm{mg} \mathrm{L}^{-1}\right)$, Al (1.5, 0.5, $\left.0.03 \mathrm{mg} \mathrm{L}^{-1}\right)$, and $\mathrm{Fe}\left(41,12,5 \mu \mathrm{g} \mathrm{L}^{-1}\right)$ confirms podzolization to be the main pedogenic process. In summary, we conclude feldspar weathering to be of very low influence on DSi concentrations.

\subsection{Dissolution of biogenic Si pool}

The biogenic Si pool contains the phytogenic and the zoogenic Si pool, both of which differ remarkably in dynamics and turnover rates. The annual biosilicification of idiosomic amoebae by binary fission adds up to $17 \mathrm{~kg} \mathrm{Si} \mathrm{ha}^{-1}$ which is in the order of magnitude of the Si flux by litterfall, hence phytogenic silicification. On the other hand, the idiosomic Si pool of $2 \mathrm{~kg} \mathrm{Si} \mathrm{ha}^{-1}$ is comparatively small. Empty tests comprise only $40 \%\left(0.8 \mathrm{~kg} \mathrm{Si} \mathrm{ha}^{-1}\right)$ of total idiosomic Si pool, while living amoebae make up $60 \%\left(1.2 \mathrm{~kg} \mathrm{Si} \mathrm{ha}^{-1}\right)$. This leads to our conclusion of a very high solubility of the idiosomic Si pool. Consequently, turnover rates are too high for interannual pool changes to become relevant for DSi exports.

Annual biosilicification by plants sums up to $35 \mathrm{~kg} \mathrm{Si} \mathrm{ha}^{-1}$, most of which is returned to the soil by litterfall. Compared to the phytolith Si pool of $660 \mathrm{~kg} \mathrm{Si} \mathrm{ha}^{-1}$ this flux is relatively large, hence residence time is rather short (pool/flux $=19 \mathrm{yr}$ ). Therefore decadal changes of phytogenic
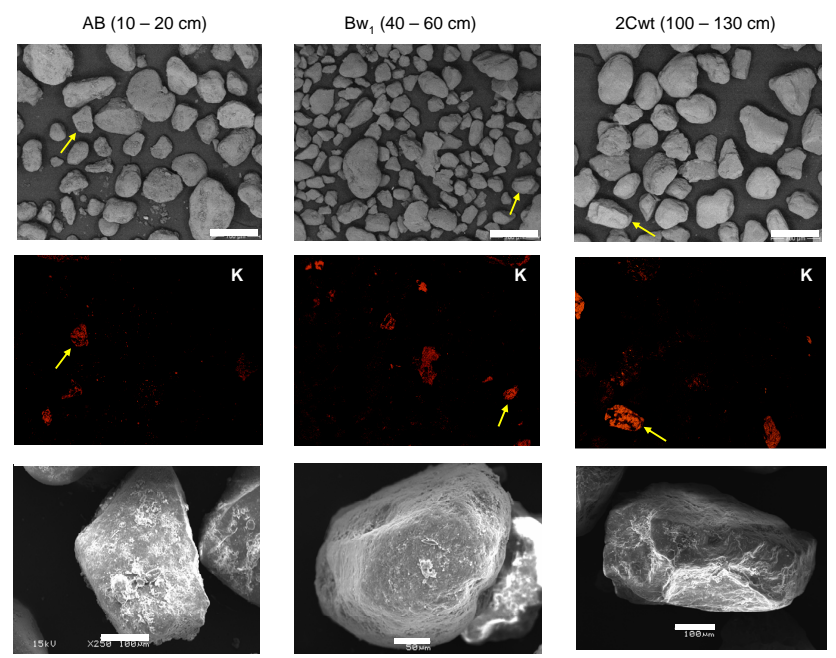

Fig. 6. SEM-micrographs and EDX element mapping (K) of soil material $(<2 \mathrm{~mm})$ from three different depths; scale bars: upper row $=700 \mu \mathrm{m}$; lower row, left and right $=100 \mu \mathrm{m}$, middle $=50 \mu \mathrm{m}$; yellow arrows point to orthoclase mineral grains shown in lower row.

Si pools are relevant for DSi exports in principal. Early experiments on phytolith dissolution in distilled water showed silicic acid equilibrium concentrations of $2-10 \mathrm{mg} \mathrm{Si} \mathrm{L}^{-1}$ (Bartoli and Wilding, 1980) depending on plant species as well as surface area. These concentrations were higher than those determined for quartz $\left(1 \mathrm{mg} \mathrm{Si} \mathrm{L}^{-1}\right)$, but lower than synthesised pure silica gels $\left(56 \mathrm{mg} \mathrm{Si} \mathrm{L}^{-1}\right)$. The latter might be closer to solubilities of nm-sized phytogenic Si. Recent experiments on the reactivity of plant phytoliths in soil solutions have shown the solubility product to be close 


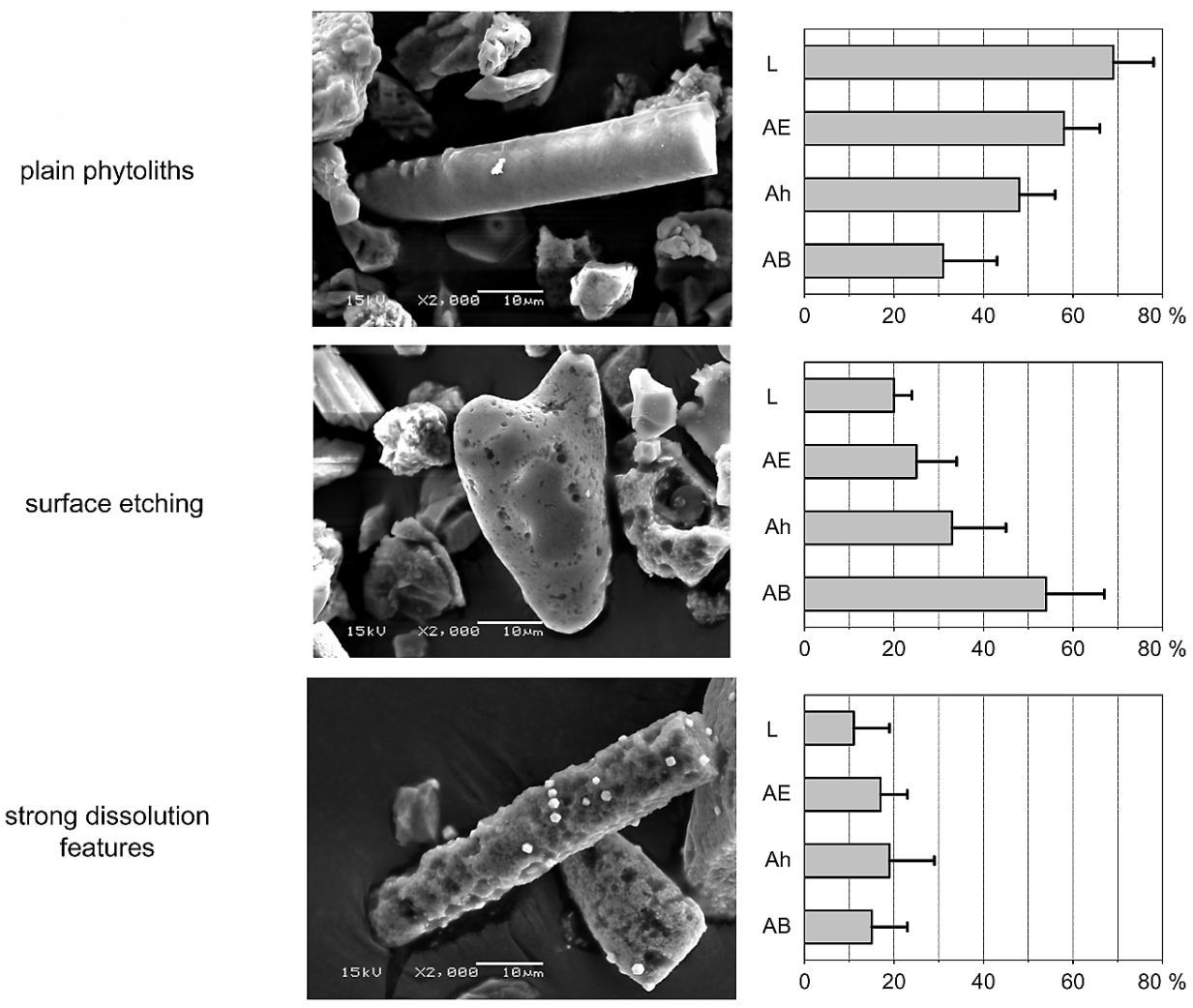

Fig. 7. Categories and depth functions of phytolith dissolution (based on counting in SEM micrographs): fresh, plain phytoliths (upper), phytoliths showing clear signs of surface etching (middle), and phytoliths showing strong dissolution features (lower); horizontal bars $=$ mean $\pm \mathrm{SD}$ ( $n=10$ micrographs), total number of phytoliths counted: $\mathrm{L}=462, \mathrm{AE}=459, \mathrm{Ah}=422, \mathrm{AB}=238$.

to that of amorphous silica and up to one order of magnitude higher than those of clay minerals (Fraysse et al., 2009, 2010). Half-life times of the studied phytoliths range from $10-12 \mathrm{yr}(\mathrm{pH}<3)$ to $<1 \mathrm{yr}(\mathrm{pH}>6)$. From these studies it is concluded that phytoliths represent a very reactive $\mathrm{Si}$ pool in soil solutions which contributes substantially to DSi.

To check the status of phytolith dissolution in our soil we defined three classes of increasing dissolution and counted assigned phytoliths in SEM micrographs (Fig. 7). The percentage of plain phytoliths showing no signs of dissolution or surface etching significantly decreased from $69 \%$ at the soil surface to $31 \%$ in the AB horizon $(10-20 \mathrm{~cm})$. Simultaneously phytoliths showing slight surface etching increased to $54 \%$. Strongly dissoluted phytoliths revealed a maximum of $19 \%$ in $\mathrm{Ah}(2-10 \mathrm{~cm})$, but no clear trend with depth. Combining these findings with (i) the observation of missing fresh beech phytoliths in soil horizons (see Sect. 3.2), and (ii) the parallel increase of water-soluble Si with phytolith $\mathrm{Si}$ pool (upper $25 \mathrm{~cm}$ ), we regard dissolution of phytogenic $\mathrm{Si}$ as the most important driver of DSi concentrations, hence DSi exports.

The influence of phytogenic Si on DSi must be regarded even stronger as the total phytogenic Si pool in soils is definitely higher than the phytolith Si pool. Only the $>5 \mu \mathrm{m}$ frac- tions of soil horizons are quantified by phytolith separation procedure (see Sect. 2.3). Comparing the Si content of leaves calculated on basis of the phytolith content with measured $\mathrm{Si}$ content supports this consideration: the calculated Si content of $2.4 \mathrm{~g} \mathrm{~kg}^{-1}$ (Table $2 \mathrm{a}$ ) only comprises $55 \%$ of the measured Si content of $4.4 \mathrm{~g} \mathrm{~kg}^{-1}$ (Table $2 \mathrm{a}$ ). BSi in the $<2 \mu \mathrm{m}$ fraction probably explains this difference, because this fraction is lost during phytolith extraction procedure. In their early work Wilding and Drees (1971) quantified $50 \%$ of total leaf opal (Fagus grandifolia) in the $<2 \mu \mathrm{m}$ fraction, another $22 \%$ in the 2-5 $\mu \mathrm{m}$ fraction. Watteau and Villemin (2001) provided evidence for nm-size phytogenic Si granules in leaves and soils. This fraction has a higher reactivity in soil solutions compared to phytoliths due to its higher surface : volume ratio.

Our conclusion about BSi as the main driver for the DSi observed is indirectly supported by process-based modeling of the Si cycle in a forest biogeosystem (Gerard et al., 2008). In a Cambisol from volcanic tuff - containing less quartz $(30 \%)$ and higher percentages of clays and weatherable minerals (K-feldspars) compared to our site - the BSi still account for $60 \%$ of DSi after all. Finally, as grasses - which are now absent at the beech stand - contribute a major part to recent phytolith pool, we concluded the phytogenic Si pool 
not to be at steady state, but transient state: the continuous decomposition of the relictic phytogenic Si pool is actually not compensated by an equivalent upbuilding.

\section{Conclusions}

Our studied forest biogeosystem exhibits surprisingly high DSi concentrations and exports compared to the very low content of weatherable minerals in soil and sediments. From our findings we excluded geochemical weathering processes as a major control on DSi, but concluded a strong biogenic footprint on $\mathrm{DSi}$. The disappearance of Si-rich grasses during canopy closure as well as pine logging $30 \mathrm{yr}$ ago seems to be the ultimate reason for the phenomena observed. The related phytogenic Si pool is in disequilibrium with recent vegetation and is dissolving successively. This has to be confirmed by $\mathrm{Si}$ isotope analysis of the different phases like it has been done in Cornelis et al. (2010b), Engström et al., (2010), Opfergelt et al. (2010), or Steinhoefel et al. (2011). Furthermore, phytolith dissolution experiments on grasses are needed in future research to understand the dissolution kinetics of Si-rich species, like Calamogrostis epigejos.

We regard our study as another example highlighting the importance of disturbances and perturbations in $\mathrm{Si}$ cycling (Ittekot et al., 2006; Laruelle et al., 2009; Struyf et al., 2010; Clymans et al., 2011; Struyf and Conley, 2012). Our study complements the conceptual model of Struyf et al. (2010). It adds vegetation changes by forest mangement, i.e., without dramatic LUC, as another driver for transient state Si cycling. Future research on Si cycling should explicitly consider decadal transient states and their main drivers.

\section{Supplementary material related to this article is available online at: http://www.biogeosciences.net/10/ 4991/2013/bg-10-4991-2013-supplement.pdf.}

Acknowledgements. First of all the authors would like to thank three anonymous reviewers for very helpful comments as well as Jürgen Kesselmeier for editing. Further we would like to thank Angela Müsebeck, Matthias Lemme, Regina Richter, Jürgen Beutler, and Michael Bähr for technical assistance and collecting samples at Beerenbusch, Dagmar Schulz for chemical analysis of samples, Dietmar Lüttschwager for providing data on sap flow analyses. Martin Kaupenjohann (TU Berlin), Francois Galbert and Jörg Nissen supported and performed EDX analysis at ZELMI (TU Berlin). Alexander Konopatzky (LFE Brandenburg, Eberswalde) provided historical data of soil and vegetation surveys. We are deeply grateful about his support. Alexandra Golyeva and Chad Yost from the Phy-Talk forum provided help in identifying vegetation from phytoliths. This study was funded by the German Research Foundation (DFG) - PAK 179 "Multiscale analysis of Si cycling in terrestrial biogeosystems".

Edited by: J. Kesselmeier

\section{References}

Alexandre, A., Meunier, J. D., Colin, F., and Koud, J. M.: Plant impact on the biogeochemical cycle of silicon and related weathering processes, Geochim. Cosmochim. Ac., 61, 677-682, 1997.

Alexandre, A., Bouvet, M., and Abbadie, L.: The role of savannas in the terrestrial Si cycle: A case study from Lamto, Ivory Coast, Global Planet. Change, 78, 162-169, 2011.

Altherr, E., Unfried, P., Hradetzky, J., and Hradetzky, V.: Statistische Rindenbeziehungen als Hilfsmittel zur Ausformung und Aufmessung unentrindeten Stammholzes, Mitteilungen der Forstlichen Versuch- und Forschungsanstalt BadenWürttemberg, 61, 1-137, 1974.

Anderson, O. A.: Cytoplasmic origin and surface deposition of siliceous structures in Sarcodina, Protoplasma, 181, 61-77, 1994.

Aoki, Y., Hoshino, M., and Matsubara, T.: Silica and testate amoebae in a soil under pine-oak forest, Geoderma, 141, 29-35, 2007.

Bartoli, F. and Souchier, B., Cycle et role du silicium d'origine végétale dans les écosystemes forestiers tempéres, Ann. Sci. Forest., 35, 187-202, 1978.

Bartoli, F. and Wilding, L. P.: Dissolution of biogenic opal as a function of its physical and chemical properties, Soil Sci. Soc. Am J., 44, 873-878, 1980.

Biermans, V. and Baert, L.: Selective extraction of the amorphous $\mathrm{Al}, \mathrm{Fe}$ and $\mathrm{Si}$ oxides using an alkaline Tiron solution, Clay Miner., 12, 127-135, 1977.

Blecker, S. W., McCulley, R. L., Chadwick, O. A., and Kelly, E. F.: Biologic cycling of silica across a grassland bioclimosequence, Global Biogeochem. Cy., 20, GB3023, doi:10.1029/2006GB002690, 2006.

Borrelli, N., Alvarez, M. F., Osterrieth, M. L., and Marcovecchio, J. E.: Silica content in soil solution and its relation with phytolith weathering and silica biogeochemical cycle in Typical Argiudolls of the Pampean Plain, Argentina - a preliminary study, J. Soils Sediments, 10, 983-994, 2010.

Carey, J. C. and Fulweiler, R. W.: Human activities directly alter watershed dissolved silica fluxes, Biogeochemistry, 111, 125-138, 2012.

Chartres, C. J.: The composition and formation of grainy void cutans in some soils with textural contrast in Southeastern Australia, Geoderma, 39, 209-233, 1987.

Clymans, W., Struyf, E., Govers, G., Vandevenne, F., and Conley, D. J.: Anthropogenic impact on amorphous silica pools in temperate soils, Biogeosciences, 8, 2281-2293, doi:10.5194/bg-8-22812011, 2011.

Conley, D. J., Likens, G. E., Buso, D. C., Saccone, L., Bailey, S. W., and Johnson, C. E.: Deforestation causes increased dissolved silicate losses in the Hubbard Brook Experimental Forest, Glob. Change Biol., 14, 2548-2554, 2008.

Cornelis, J. T., Ranger, J., Iserentant, A., and Delvaux, B.: Tree species impact the terrestrial cycle of silicon through various uptakes, Biogeochem., 97, 231-245, 2010a.

Cornelis, J. T., Delvaux, B., Cardinal, D., Andre, L., Ranger, J., and Opfergelt, S.: Tracing mechanisms controlling the release of dissolved silicon in forest soil solutions using $\mathrm{Si}$ isotopes and $\mathrm{Ge} / \mathrm{Si}$ ratios, Geochim. Cosmochim. Ac., 74, 3913-3924, 2010b.

Cornelis, J. T., Titeux, H., Ranger, J., and Delvaux, B.: Identification and distribution of the readily soluble silicon pool in a temperate forest below three distinct tree species, Plant Soil, 342, 369-378, 2011a. 
Cornelis, J.-T., Delvaux, B., Georg, R. B., Lucas, Y., Ranger, J., and Opfergelt, S.: Tracing the origin of dissolved silicon transferred from various soil-plant systems towards rivers: a review, Biogeosciences, 8, 89-112, doi:10.5194/bg-8-89-2011, 2011 b.

Cornu, S., Lucas, Y., Ambrosi, J. P., and Desjardins, T.: Transfer of dissolved $\mathrm{Al}, \mathrm{Fe}$ and $\mathrm{Si}$ in two Amazonian forest environments in Brazil, Eur. J. Soil Sci., 49, 377-384, 1998.

Dietz, P.: Dichte und Rindengehalt von Industrieholz, Holz Roh. Werkst., 33, 135-141, 1975.

DIN ISO 1039.: Bodenbeschaffenheit: Bestimmung des pH-Wertes, Deutsches Institut für Normung, Beuth, Berlin, 1997.

DIN ISO 11277: Bodenbeschaffenheit: Bestimmung der Partikelgrößenverteilung in Mineralböden - Verfahren mittels Siebung und Sedimentation, Deutsches Institut für Normung, Beuth, Berlin, 1998.

Dittmar, O., Knapp, E., and Lembcke, G.: DDR-Buchenertragstafel 1983, Institut für Forstwissenschaften Eberswalde, Eberswalde, 1986.

do Nascimento, N. R., Fritsch, E., Bueno, G. T., Bardy, M., Grimaldi, C., and Melfi, A. J.: Podzolization as a deferralitization process: dynamics and chemistry of ground and surface waters in an Acrisol - Podzol sequence of the upper Amazon Basin, Eur. J. Soil Sci., 59, 911-924, 2008.

Dove, P. M.: Kinetic and thermodynamic controls on silica reactivity in weathering environments, in: Chemical weathering rates of silicate minerals, Mineralogical Society of America and the Geochemical Society, Rev. Mineral. Geochem., 31, 235-290, 1995.

Ehrmann, O., Puppe, D., Wanner, M., Kaczorek, D., and Sommer, M.: Testate amoebae in 31 mature forest ecosystems - densities and micro-distribution in soils, Eur. J. Protistol., 48, 161-168, doi:10.1016/j.ejop.2012.01.003, 2012.

Ellenberg, H., Mayer, R., and Schauermann, J.: Ökosystemforschung - Ergebnisse des Sollingprojekts 19661986, Verlag Eugen Ulmer, Stuttgart, 1986.

Engle, D. L., Sickman, J. O., Moore, C. M., Esperanza, A. M., Melack, J. M., and Keeley, J. E.: Biogeochemical legacy of prescribed fire in a giant sequoia-mixed conifer forest: A 16-year record of watershed balances, J. Geophys. Res., 113, G01014, doi:10.1029/2006JG000391, 2008.

Engström, E., Rodushkin, I., Ingri, J., Baxter, D. C., Ecke, F., Österlund, H., and Öhlander, B.: Temporal isotopic variations of dissolved silicon in a pristine boreal river, Chem. Geol., 271, 142-152, 2010.

Fraysse, F., Pokrovsky, O. S., Schott, J., and Meunier, J.-D.: Surface chemistry and reactivity of plant phytoliths in aqueous solutions, Chem. Geol., 258, 197-206, 2009.

Fraysse, F., Pokrovsky, O. S., and Meunier, J.-D.: Experimental study of terrestrial plant litter interaction with aqueous solutions, Geochim. Cosmochim. Ac., 74, 70-84, 2010.

Gerard, F., Francois, M., and Ranger, J.: Processes controlling silica concentration in leaching and capillary soil solutions of an acidic brown forest soil (Rhone, France), Geoderma, 107, 197226, 2002.

Gerard, F., Mayer, K. U., Hodson, M. J., and Ranger, J.: Modelling the biogeochemical cycle of silicon in soils: Application to a temperate forest ecosystem, Geochim. Cosmochim. Ac., 72, 741758,2008

Ginzel, G., and Ertl, C.: Geologie, Hydrologie und Klima, in: Das Naturschutzgebiet Stechlin, edited by: Lütkepohl, M. and Flade,
M., Natur \& Text in Brandenburg, Rangsdorf, 15-23, 2004.

Golyeva, A.: Phytoliths and their information role in natural and archaeological objects, Moscow, Syktyvkar Elista, 2001.

Grady, A. E., Scanlon, T. M., and Galloway, J. N.: Declines in dissolved silica concentrations in western Virginia streams (19882003): Gypsy moth defoliation stimulates diatoms?, J. Geophys. Res., 112, G01009, doi:10.1029/2006JG000251, 2007.

Granier, A.: Une novelle methode pour la mesure du flux de serve brute dans le tronc des arbres, Ann. Sci. Forest., 42, 193-200, 1985.

Guntzer, F., Keller, C., and Meunier, J.-D.: Determination of the silicon concentration in plant material using Tiron extraction, New Phytol., 188, 902-906, 2010.

Hodson, M. J., White, P. J., Mead, A., and Broadley, M. R.: Phylogenetic variation in the silicon composition of plants, Ann. Bot., 96, 1027-1046, 2005.

Iler, R. K.: The chemistry of silica, Wiley-Interscience, New York, 1979.

Ittekot, V., Unger, D., Humborg, C., and Tac An, N. (Eds.): The silicon cycle - Human perturbations and impacts on aquatic systems, SCOPE 66, Island Press, Washington, 2006.

Jochheim, H., Einert, P., Ende, H.-P., Kallweit, R., Lüttschwager, D., and Schindler, U.: Wasser-und Stoffhaushalt eines BuchenAltbestandes im Nordostdeutschen Tiefland - Ergebnisse einer 4jährigen Messperiode, Archiv für Forstwesen und Landschaftsökologie, 41, 1-14, 2007a.

Jochheim, H., Puhlmann, M., and Pohle, D.: Implementation of a forest management module into BIOME-BGC and its application, EOS Transactions Supplement, 88, B24A-04, 2007b.

Jochheim, H., Puhlmann, M., Beese, F., Berthold, D., Einert, P., Kallweit, R., Konopatzky, A., Meesenburg, H., Meiwes, K. J., Raspe, S., Schulte-Bisping, H., and Schulz, C.: Modelling the carbon budget of intensive forest monitoring sites in Germany using the simulation model BIOME-BGC, iForest, 2, 7-10, 2009.

Kendrick, K. J. and Graham, R. C.: Pedogenic silica accumulation in chronosequence soils, Southern California, Soil Sci. Soc. Am. J., 68, 1295-1303, 2004.

Kodama, H. and Ross, G. J.: Tiron dissolution method used to remove and characterize inorganic components in soils, Soil Sci. Soc. Am. J., 55, 1180-1187, 1991.

Lachmann, M.: Intensität und räumliche Verteilung der Durchwurzelung im Buchenbestand in Abhängigkeit von den Bodenbedingungen auf einer Dauerbeobachtungsfläche, BSc. Thesis, International Forest Ecosystem Management, FH Eberswalde, 2002.

Laruelle, G. G., Roubeix, V., Sferratore, A., Brodherr, B., Ciuffa, D., Conley, D. J., Dürr, H. H., Garnier, J., Lancelot, C., Le Thi Phuong, Q., Meunier, J.-D., Meybeck, M., Michalopoulos, P., Moriceau, B., Ní Longphuirt, S., Loucaides, S., Papush, L., Presti, M., Ragueneau, O., Regnier, P., Saccone, L., Slomp, C. P., Spiteri, C., and Van Cappellen, P.: Anthropogenic perturbations of the silicon cycle at the global scale: Key role of the land-ocean transition, Global Biogeochem. Cy., 23, GB4031, doi:10.1029/2008GB003267, 2009.

Li, H., Jun, H., Wenfeng, T., Hongqing, H., Fan, L., and Mingkuang, W.: Characteristics of micromorphology and element distribution of iron-manganese cutans in typical soils of subtropical China, Geoderma, 146, 40-47, 2008. 
Lucas, Y.: The role of plants in controlling rates and products of weathering: Importance of biological pumping, Annu. Rev. Earth Planet. Sci., 29, 135-163, 2001.

Lüttschwager, D. and Remus, R.: Radial distribution of sap flux density in trunks of a mature beech stand, Ann. Sci. Forest., 64, 431-438, 2007.

Madella, M., Alexandre, A., and Ball, T.: International code for phytolith nomenclature 1.0, Ann. Bot., 96, 253-260, 2005.

McKeague, J. A. and Cline, M. G.: Silica in soil solutions I. The form and concentration of dissolved silica in aqueous extracts of some soils, Can. J. Soil Sci., 43, 70-82, 1963.

Mehra, O. P. and Jackson, M. L.: Iron oxide removal from soils and clays by a dithionite-citrate system buffered with sodium bicarbonate, in: Clays and Clay Minerals, edited by: Swineford, A., Proc. 7th Natl. Conf., Washington DC, 1958, Pergamon Press, New York, 317-327, 1960.

Meisterfeld, R.: Order Arcellinida Kent, 1880, in: An Illustrated Guide to the Protozoa, 2nd Edition, edited by: Lee J. J., Leedale, G. F., and Bradbury, P., Society of Protozoologists, Lawrence, 827-860, 2002a.

Meisterfeld, R.: Testate amoebae with filopodia, in: An Illustrated Guide to the Protozoa, 2nd Edition, edited by: Lee J. J., Leedale, G. F., and Bradbury, P., Society of Protozoologists, Lawrence, 1054-1084, 2002b.

Melzer, S. E., Knapp, A. K., Kirkman, K. P., Smith, M. D., Blair, J. M., and Kelly, E. F.: Fire and grazing impacts on silica production and storage in grass dominated ecosystems, Biogeochem., 97, 263-278, 2010.

Melzer, S. E., Chadwick, O. A., Hartshorn, A. S., Khomo, L. M., Knapp, A. K., and Kelly, E. F.: Lithological controls on biogenic silica cycling in South African savanna ecosystems, Biogeochem., 108, 317-334, doi:10.1007/s10533-011-9602-2, 2012.

Opfergelt, S., Cardinal, D., Andre, L., Delvigne, C., Bremond, L., and Delvaux, B.: Variations of $\delta^{30} \mathrm{Si}$ and $\mathrm{Ge} / \mathrm{Si}$ with weathering and biogenic input in tropical basalt ash soils under monoculture, Geochim. Cosmochim. Ac., 74, 225-240, 2010.

Patel-Sorrentino, N., Lucas, Y., Eyrolle, F., and Melfi, A. J.: Fe, Al and Si species and organic matter leached off a ferrallitic and podzolic soil system from Central Amazonia, Geoderma, 137, 444-454, 2007.

Pavlov, M. B.: Bioelement-Inventur von Buchen- und Fichtenbeständen im Solling, Göttinger Bodenkundliche Berichte, 25, 1-174, 1972.

Puhlmann, M. and Jochheim, H.: Implementation of a multi-layer soil model into Biome-BGC- calibration and application, EOS Transactions Supplement, 88, B24A-05, 2007.

Saccone, L., Conley, D. J., Koning, E., Sauer, D., Sommer, M., Kaczorek, D., Blecker, S. W., and Kelly, E. F.: Assessing the extraction and quantification of amorphous silica in soils of forest and grassland ecosystems, Eur. J. Soil Sci., 58, 1446-1459, 2007.

Sauer, D., Saccone, L., Conley, D. J., Herrmann, L., and Sommer, M.: Review of methodologies for extracting plant-available and amorphous Si from soils and aquatic sediments, Biogeochem., 80, 89-108, 2006.

Schachtschabel, P. and Heinemann, C. G.: Wasserlösliche Kieselsäure in Lößböden, Z. Pflanzenern. Bodenk., 118, 22-35, 1967.
Schlichting, E., Blume, H. P., and Stahr, K.: Soils Practical (in German), Blackwell, Berlin, Wien, Germany, Austria, 1995.

Schönborn, W.: Ermittlung der Jahresproduktion von BodenProtozoen. I. Euglyphidae (Rhizopoda, Testacea), Pedobiologia, 15, 415-424, 1975.

Schönborn, W.: Estimation of annual production of Testacea (Protozoa) in mull and moder (II), Pedobiologia, 23, 383-393, 1982.

Schwertmann, U.: Differenzierung der Eisenoxide des Bodens durch Extraktion mit Ammoniumoxalat Lösung, Z. Pflanzenern. Bodenk., 105, 194-202, 1964.

Soil Survey Staff: Soil Taxonomy - A basic system of soil classification for making and interpreting soil surveys, USDA-NRCS, Agriculture Handbook 436, http://soils.usda.gov/ technical/classification/taxonomy, 1999.

Sommer, M., Kaczorek, D., Kuzyakov, Y., and Breuer, J.: Silicon pools and fluxes in soils and landscapes - a review, J. Plant Nutr. Soil Sci., 169, 310-329, 2006.

Steinhoefel, G., Breuer, J., Blanckenburg, F., Horn, I., Kaczorek, D., and Sommer, M.: Micrometer silicon isotope diagnostics of soils by UV femtosecond laser ablation, Chem. Geol., 286, 280-289, 2011.

Stoops, G.: Guidelines for analysis and description of soil and regolith thin sections, Soil Sci. Soc. Am., Madison, WI, 2003.

Struyf, E. and Conley, D. J.: Silica: an essential nutrient in wetland biogeochemistry, Front. Ecol. Environ., 7, 88-94, doi:10.1890/070126, 2009.

Struyf, E. and Conley, D. J.: Emerging understanding of the ecosystem silica filter, Biogeochem., 107, 9-18, 2012.

Struyf, E., Opdekamp, W., Backx, H., Jacobs, S., Conley, D. J., and Meire, P.: Vegetation and proximity to the river control amorphous silica storage in a riparian wetland (Biebrza National Park, Poland), Biogeosciences, 6, 623-631, doi:10.5194/bg-6623-2009, 2009.

Struyf, E., Smis, A., Van Damme, S., Garnier, J., Govers, G., Van Wesemael, B., Conley, D. J., Batelaan, O., Frot, E., Clymans, W., Vandevenne, F., Lancelot, C., Goos, P., and Meire, P.: Historical land use change has lowered terrestrial silica mobilization, Nat. Commun., 1, 129, doi:10.1038/ncomms1128, 2010.

Thornton, P. E., Law, B. E., Gholz, H. L., Clark, K. L., Falge, E., Ellsworth, D. S., Golstein, A. H., Monson, R. K., Hollinger, D., Falk, M., Chen. J., and Sparks, J. P.: Modelling and measuring the effects of disturbance history and climate on carbon and water budgets in evergreen needle leaf forests, Agr. Forest Meteorol., 113, 185-222, 2002.

Trendelenburg, R. and Mayer-Wegelin, H.: Das Holz als Rohstoff, Hanser, München, 1955.

Wanner, M.: A review on the variability of testate amoebae: Methodological approaches, environmental influences and taxonomical implications, Acta Protozool., 38, 15-29, 1999.

Wanner, M. and Dunger, W.: Biological activity of soils from reclaimed open-cast coal mining areas in Upper Lusatia using testate amoebae (protists) as indicators, Ecol. Eng. 17, 323-330, 2001.

Watteau, F. and Villemin, G.: Ultrastructural study of the biogeochemical cycle of silicon in the soil and litter of a temperate forest, Eur. J. Soil Sci., 52, 385-396, 2001.

White, A. F., Schulz, M. S., Vivit, D. V., Blum, A. E., Stonestrom, D. A., and Anderson, S. P.: Chemical weathering of a marine terrace chronosequence, Santa Cruz, California I: Interpreting 
rates and controls based on soil concentration-depth profiles, Geochim. Cosmochim. Acta, 72, 36-68, 2008.

White, A. F., Vivit, D. V., Schulz, M. S., Bullen, T. D., Evett, R. R., and Aagarwal, J. : Biogenic and pedogenic controls on Si distributions and cycling in grasslands of the Santa Cruz soil chronosequence, California, Geochim. Cosmochim. Ac., 94, 72-94, 2012.
Wilding, L. P. and Drees, L. R.: Biogenic opal in Ohio soils, Soil Sci. Soc. Am. Proc., 35, 1004-1010, 1971.

WRB-World reference base for soil resources, World Soil Resources Reports, 103, p. 128, Rome, FAO, 2006. 